4-1981

\title{
Evidence on the "Tax Effects" of Inflation Under Historical Cost Accounting Methods
}

Nicholas J. Gonedes

University of Pennsylvania

Follow this and additional works at: http://repository.upenn.edu/accounting_papers

Part of the Accounting Commons, and the Taxation Commons

\section{Recommended Citation}

Gonedes, N. J. (1981). Evidence on the "Tax Effects" of Inflation Under Historical Cost Accounting Methods. The Journal of Business, 54 (2), 227-270. Retrieved from http://repository.upenn.edu/accounting_papers/75

This article is available online at: http://www.jstor.org/stable/2352676

This paper is posted at ScholarlyCommons. http://repository.upenn.edu/accounting_papers/75

For more information, please contact repository@pobox.upenn.edu. 


\title{
Evidence on the "Tax Effects" of Inflation Under Historical Cost Accounting Methods
}

\begin{abstract}
It is often argued that the failure to use indexation (i.e., the use of historical cost accounting methods) implies that real income tax rates will vary directly with rates of inflation. This substantive effect of mere bookkeeping methods is often predicted even though it is recognized to have some adverse implications. This is the "tax effects of inflation" hypothesis. The major objective of this paper is to examine the descriptive adequacy of this hypothesis using a variety of macro- economic data for the years 1929-74. My empirical results appear to be substantially inconsistent with the tax- effects hypothesis.
\end{abstract}

\section{Disciplines}

Accounting | Taxation

\section{Comments}

This article is available online at: http://www.jstor.org/stable/2352676 


\section{Evidence on the "Tax Effects" of Inflation under Historical Cost Accounting Methods*}

\section{Introduction}

The potential effects of contemporary tax accounting methods under conditions of inflation have attracted substantial attention (see, e.g., Shoven and Bulow 1975, 1976; Davidson and Weil 1976; Nelson 1976; Hong 1977; and Kim 1979). In particular, there has been substantial interest in the potential joint effects of price-level changes and historical cost accounting methods on real tax burdens. It is usually argued that the failure to use indexation (i.e., the continued use of historical cost methods) necessarily implies that real rates of income tax will vary directly with the rate of inflation. And this substantive effect of mere bookkeeping methods is often predicted even though the predicted effect is recognized to have adverse implications-such as

* Earlier versions of this paper were presented at workshops sponsored by Stanford University and the University of Pennsylvania. I am indebted to the participants in these workshops for helpful comments and for motivating me to rethink many points. I benefited from numerous discussions with Gene Fama on this topic. The crux of my results and arguments are basically consistent with those given in Fama's recent report on this topic (see Fama March 1979). Additional special thanks are due to Mark Wolfson, Shyam Sunder, George Foster, Meir Schneller, Katherine Schipper, and Tom Stober. Partial financial support from the National Science Foundation and the Peat, Marwick, Mitchell \& Co. Foundation is gratefully acknowledged, as is the incredible research assistance provided by Bruce Lederman and Mike Axelrod.

(Journal of Business, 1981, vol. 54. no. 2)

(C) 1981 by The University of Chicago

$0021-9398 / 81 / 5402-0002 \$ 01.50$
It is often argued that the failure to use indexation (i.e., the use of historical cost accounting methods) implies that real income tax rates will vary directly with rates of inflation. This substantive effect of mere bookkeeping methods is often predicted even though it is recognized to have some adverse implications. This is the "tax effects of inflation", hypothesis. The major objective of this paper is to examine the descriptive adequacy of this hypothesis using a variety of macroeconomic data for the years 1929-74. My empirical results appear to be substantially inconsistent with the taxeffects hypothesis. 
those predicted for investment incentives and productivity. This appears to be the essence of the "tax effects of inflation" hypothesis. A terse but representative statement of its implications for fixed capital was recently provided by Meadows (1979, pp. 38-39) in an article on taxation and incentives: "As prices rise, the real value of depreciation based on historic costs dwindles and a company's taxable income goes up faster than it would if depreciation reflected actual replacement costs. The resulting erosion of corporate income lowers return on investment and discourages businessmen from putting money into capital-intensive technologies, long-lived assets, and new, more efficient replacement equipment."

The major objective of this paper is to provide empirical evidence on some testable implications of this hypothesis. I shall argue that this evidence is, on balance, inconsistent with the tax-effects hypothesis-at least for the post-World War II period. This evidence is consistent with the hypothesis that the ultimate effects of indexing the tax system have been attained via devices other than formal indexation.

This evidence does not, of course, imply that the tax-effects hypothesis does not describe what might have happened if "all other things"-including the rules of income taxation-were held constant. The apparent descriptive inadequacies of this hypothesis may simply be due to important changes in these "other things"-changes which are ignored by the partial equilibrium framework underlying the taxeffects hypothesis.

The organization of this paper is as follows: Section II provides a review of the tax-effects hypothesis and some of its implications. The data and models underlying our empirical results are considered in Section III, and the results themselves are presented and discussed in Section IV. Remarks on potential reasons for the descriptive inadequacy of the tax-effects hypothesis are provided in Section V. A summary and discussion of basic implications are provided in Section VI. Most arguments in all sections are expressed in terms of positive inflation rates. Obvious analogous arguments apply to negative rates.

The discussion of data given in Section IV is somewhat brief. An extended discussion with more detailed references is given in the Appendix to this paper.

\section{The Tax Effects of Inflation Hypothesis}

\section{The Basic Argument}

The tax-effects hypothesis can be decomposed into a hypothesis dealing with the expected rate of inflation and one dealing with the unexpected rate of inflation. Of course, the crux of both hypotheses turns 
on the use of "historical cost" accounting methods to compute taxable profits. But the joint effects of these methods and the expected rate of inflation on "real" economic profits and incentives may differ from the joint effects of these methods and the unexpected component of inflation.

The accounting methods that seem to attract most attention in statements of the tax-effects hypothesis are depreciation methods and inventory accounting methods. We shall confine our attention to these methods.

Given the relative prices of all final outputs and factors of production, both nominal (i.e., "current-dollar") sales and nominal costs will, for a given quantity of output, increase at a rate equal to the rate of inflation. Thus, nominal pretax "economic" profits will increase at this rate and real economic profits will remain constant. ${ }^{1}$ Given a proportional tax system based on nominal economic profits, nominal income taxes and nominal after-tax profits will also increase at the same rate. Thus, the real rate of taxation will, in this scenario, be unaffected by nonzero rates of actual inflation. Nor will the expected real rate of taxation be affected by the expected rate of inflation. In this setting of "pure inflation" (i.e., fixed relative prices) and income taxes based on nominal economic profits, neither the expected nor the unexpected component of inflation will, by itself, have any substantive economic effect-on, for example, incentives to invest in units of capital stock.

In a partial equilibrium analysis, the picture is entirely different when the computation of taxes is based on historical cost accounting methods for, say, depreciable assets and costs of goods sold. Nominal sales, for a given quantity of output, will increase at a rate equal to the rate of inflation. And expected nominal sales will increase at the expected rate of inflation. But actual (expected) taxable profits and after-tax accounting profits will increase at a rate exceeding the actual (expected) rate of inflation. Thus, for a given quantity of output, the actual (expected) real rate of taxation will vary directly with the actual (expected) rate of inflation.

The same tax effect of a once-over unexpected rate of inflation could be attained in a zero-inflation world, for the same level of output, by unexpectedly increasing the tax rate applied to periodic profits over the remaining lives of depreciable assets currently on hand and over the additional periods needed to substitute current costs for the historical costs of units currently in inventory. A similar equivalence exists

1. By nominal "economic" profits, I mean profits computed in terms of the currently prevailing prices of outputs and of the services provided by factors of production. Real economic profits equals nominal profits after abstracting from general price level changes. Going from nominal to real profits involves, at an operational level, some heady issues of price-index construction which we bypass here (for extensive discussions of this topic, see Griliches [1971]). 
betweeen a nonzero expected rate of inflation and an increasing expected tax rate in a world of no inflation, since the rate of change in the real tax rate varies directly with the rate of inflation, conditional on the pattern of output and investment outlays and the use of historical cost accounting methods for computing taxable profits.

These relationships between the real rate of taxation and the rate of inflation provide the basic underpinnings of the tax-effects hypothesis. Conditional on these relationships, it predicts that the strength of incentives to invest in long-lived assets will vary inversely with the expected rate of inflation. It predicts an inverse relationship between actual (expected) real after-tax profits and unanticipated (expected) rates of inflation. It predicts windfall losses on existing units of capital when there is unexpected inflation or an unexpected change in expected inflation. It predicts that real aggregate taxes will increase faster than the two components of the inflation rate. It implies that the effects of both expected and unexpected inflation will be greater for more capital intensive firms. Moreover, the tax-effects hypothesis implies that these effects of expected and unexpected rates of inflation will be stronger (or at least different) in high relative to low nominal tax rate periods.

\section{Remarks on the Descriptive Adequacy of the Tax-Effects Hypothesis}

The tax-effects argument-with respect to both expected and unexpected rates of inflation-seems to have attracted a substantial following, for both theoretical and empirical reasons. ${ }^{2}$ But there are strong grounds for suspecting that it does not identify dominant influences on investment incentives or real economic profits.

One essential aspect of using historical cost accounting methods under conditions of nonzero rates of inflation is that tax deductible costs differ from the current costs of factors of production. Indexation is one of the recommended remedies for this. And the fact that our tax system is not a fully indexed one is a major underpinning of the tax-effects hypothesis.

But there are alternative ways of attaining the effects of indexation. The tax code may permit the use of service lives for depreciable assets that differ substantially from economic service lives. ${ }^{3}$ Also, it may permit the use of depreciation methods resulting in depreciation

2. Useful summaries of major positions are provided in Shoven and Bulow (1975, 1976), Aaron (1976), Cagan and Lipsey (1978), and Feldstein (1979b). The paper by Tideman and Tucker (1976) in the Aaron (1976, pp. 33-74) compilation is particularly useful.

3. The evidence presented by Cohen (1975) is consistent with tax service lives for equipment that are substantially different from those revealed by actual investment behavior, conditional on the IRS's Asset Depreciation Range (ADR) System. The differences seem to be larger for structures, conditional on a tax service-life equal to 23 years for structures. 
charges that differ substantially from the current costs of the services of capital, particularly in the early years of an asset's life (via "accelerated" depreciation methods). Moreover, various "subsidy" schemes-such as investment tax credits-may be established. Given the nature of the legislative process leading to these possibilities-in particular, the sort of "horse trading" that seems to take place-it is certainly not obvious that their availability is independent of formal indexation's availability. In other words, if the tax system were indexed, existing subsidy programs and existing rules regarding service lives and depreciation methods might be very different. These programs and rules may have been introduced in lieu of indexation. ${ }^{4}$

Why one form of indexation rather than another is ultimately chosen is not explained here. This issue may turn on administrative efficiencies, wealth redistribution objectives, "political realities," and so forth. The major object of analysis here is whether the end results of indexation were attained-and thus whether the tax-effects hypothesis is, by itself, descriptively adequate.

The descriptive adequcy of the tax-effects argument may be adversely affected by simultaneity problems, too. Specifically, expected and unexpected rates of inflation may summarize (i.e., be a proxy for) governmental responses to observed after-tax real economic profits and observed rates of increase in the capital stock. It is not clear that these components of inflation rates are really exogenous variables.

Suppose, for example, that after-tax real profits are deemed to be "too low." This may motivate the government to initiate stimulative policies that induce positive unexpected rates of inflation. Estimated correlation coefficients for unexpected rates of inflation and after-tax

4. Indeed, they may even go beyond indexation, as measured by the difference between, say, historical cost capital comsumption allowances and current value capital consumption allowances. Note, e.g., that for each of the years 1962-73, the NIPA (National Income and Products Accounts) Capital Consumption Adjustment for All Corporations was positive. This indicates that historical cost depreciation (per tax reports) exceeded the NIPA estimate of current value depreciation in each of those years. (The NIPA estimate is based on $.85 \mathrm{~F}$ service lives and straight-line depreciation.) (See The National Income and Product Accounts of the United States, 1929-1974: Statistical Tables [U.S. Department of Commerce, Bureau of Economic Analysis 1977], pp. 46-47, table 1.15, line 6.) The total NIPA adjustment can be decomposed into an adjustment for depreciation methods, but still using historical cost, and an adjustment for the difference between historical and current costs. In table 8.7 of the NIPA accounts, these two adjustments are given by, respectively, "adjustment of capital consumption allowances to consistent accounting at historical cost" and "adjustment of consistent accounting at historical cost to current replacement cost." The first adjustment is supposed to make the data for all firms conditional on SL depreciation and $.85 \mathrm{~F}$ service lives. It is, therefore, intended to abstract from "liberalized" provisions pertaining to depreciation methods and service lives. Over the 1962-73 period, this first adjustment exceeds the second adjustment, which is supposed to deal only with the difference between current and historical costs. A recent analysis of the potentially similar effects of formal indexation and accelerated depreciation methods is provided by Feldstein $(1979 a)$. 
real profits (as measured in, e.g., the National Income and Product Accounts [NIPA]) will be negative, as predicted by the tax-effects hypothesis. But this empirical result is not due to the unexpected rate of inflation's affect on real after-tax profits. This type of negative association is implied by Kurz's (1979) proposed theory of inflation, which assumes that firms follow "correlated" pricing strategies.

Inverse variation between the expected rate of inflation and capital stock growth may turn on similar forces. The government may initiate stimulative policies because the productivity of capital and (as a result) employment are "too low." These policies may induce higher expected rates of inflation. In the end, one may observe negative covariation of the expected rate of inflation and the growth of capital.

Alternative explanations of what is predicted by the tax-effects hypothesis should not be surprising. After all, empirical evidence consistent with one hypothesis may also be consistent with another, even conflicting, hypothesis. And the tax-effects hypothesis represents just one of several perspectives on the connection between inflation and profitability, investment incentives, and so forth. It appears, however, that our evidence is, on balance, not even consistent with the taxeffects hypothesis. As far as tax issues are concerned, this evidence is, therefore, apparently inconsistent with the view that accounting methods are permitted to have unintended substantive effects.

\section{Data and Models}

\section{Variables Modeled and Sources of Data}

The evidence presented here deals primarily with investment incentives (to the extent reflected in rates of investment in fixed capital), real profits, effective real tax rates, and the tax shield provided by interest deductions. In each case the variable of interest is used as the dependent variable in a regression model which uses the contemporaneous expected and unexpected rates of inflation and the contemporaneous rate of change in industrial production as independent variables. The latter rate of change is included in order to account for the effects of contemporaneous "business activity" on each dependent variable of interest. ${ }^{5}$ Accounting for these effects is motivated by the fact that many predictions of the tax-effects hypothesis are conditional on changes in business output or "business activity." The estimation results pertain to the resulting estimated regression functions, and our interpretations invoke the regression function perspective, as devel-

5. All regression model results discussed below were also obtained for models that did not include, as an independent variable, the contemporaneous rate of change in industrial production. Noteworthy differences between these unreported results and those presented here are discussed at appropriate points in the text. 
oped in, for example, Cramer (1946). For each variable of interest, we shall be interested in the expected value of that variable taken conditionally on the contemporaneous values of the expected and unexpected rates of inflation and assuming linear regression functions.

The major sources of the annual data used to compute the values of our dependent variables are: (1) The National Income and Product Accounts of the United States, 1929-1974: Statistical Tables (U.S. Department of Commerce, Bureau of Economic Analysis 1977), referred to as NIPA data; and (2) Fixed Nonresidential Business and Residential Capital in the United States, 1925-1975 (U.S. Department of Commerce, Bureau of Economic Analysis 1976), referred to as BEA data.

The data obtained from source 2 were revised in accordance with data supplied by John A. Gorman and John C. Musgrave of the Bureau of Economic Analysis; they also supplied data on inventory stocks. We refer to the latter as BEA data also.

Some of the NIPA data used here are the revised values provided in the July 1977 and July 1978 issues of the monthly Survey of Current Business (U.S. Department of Commerce 1977-78).

The Consumer Price Index (CPI) is used to measure the rate of inflation. Our data on actual and expected rates of inflation were kindly supplied by G. William Schwert of the University of Rochester.

The Federal Reserve Board's Index of Industrial Production (Total) for the year $t-1$ to $t$ is used to measure the level of output for year $t$. Annual values of this index, from the year 1919, were taken from table A-5 of Industrial Production: 1976 Edition (Federal Reserve System, Board of Governors 1977).

A variety of unreported results were obtained by using data from the U.S. Internal Revenue Service. These results are described in the January 1980 version of this report (Gonedes 1980). They did not lead to inferences substantially different from those described below.

Additional remarks on the data used here as well as our estimates of the expected annual rate of inflation are provided in the Appendix to this paper. An overview of the variables used to define the dependent variables for our estimated regression models and the sources used to get observations on these variables is provided in the unnumbered table below.

\section{Models}

Estimation results are presented for the entire period 1929-74 and for various subperiods for the following regression model:

$$
\tilde{Y}_{t}=\beta_{0}+\beta_{1} E\left(\tilde{\pi}_{t}\right)+\beta_{2}\left[\pi_{t}-E\left(\tilde{\pi}_{t}\right)\right]+\beta_{3} Y_{t-1}+\beta_{4} q_{t}+\tilde{\xi}_{t},
$$

where $\tilde{Y}_{t}$ denotes the dependent variable of interest; $q_{t}$ denotes the rate of change in industrial production from time $t-1$ to time $t ; E\left(\tilde{\pi}_{t}\right)$ 
Summary of Variables Used (Directly or to Derive Another Variable) and Sources of Data

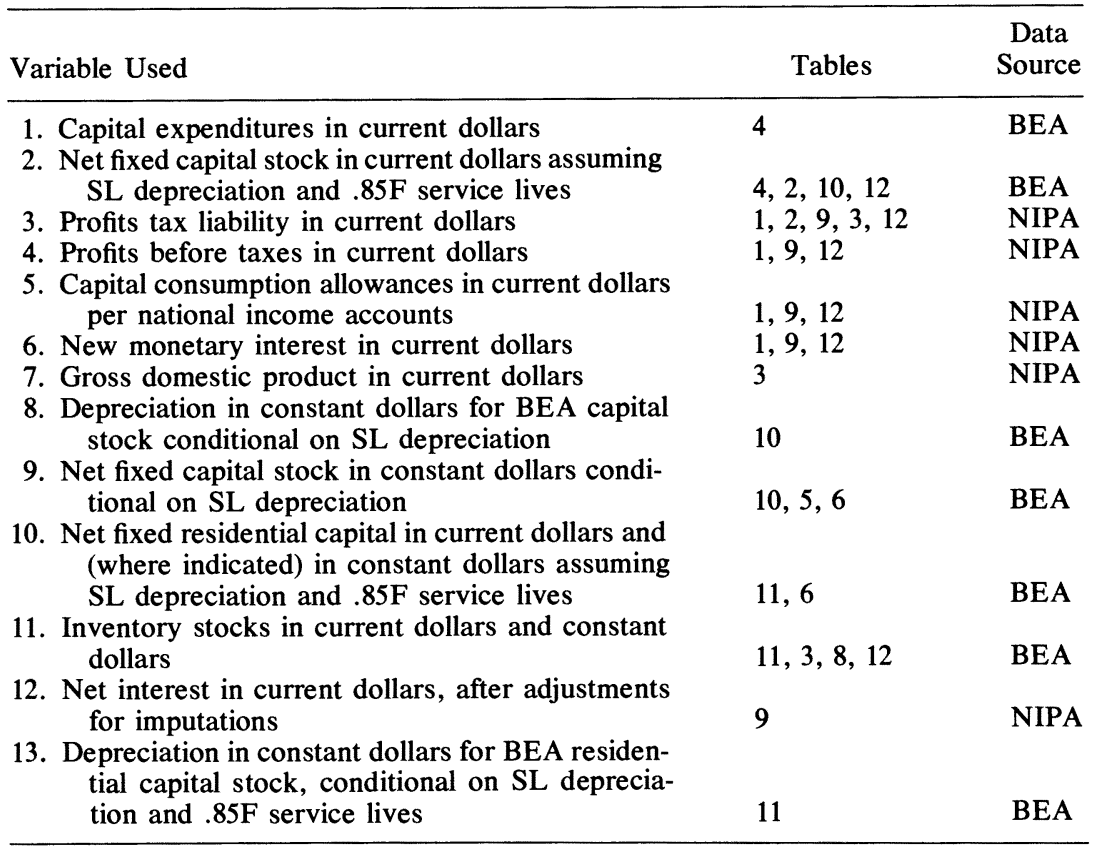

NoTE._All data are for "all corporations" and, except for gross domestic product, in millions of dollars; gross domestic product (variable 7) is in billions of dollars. Data are annual data for calendar years 1929-74. BEA = Bureau of Economic Analysis, NIPA = National Income Products Accounts.

denotes the expected annual rate of inflation for the period from $t-1$ to $t$, conditional on information available before the end of period $t$; and $\tilde{\pi}_{t}$ denotes the rate of inflation from period $t-1$ to $t$. The variable $\left[\tilde{\pi}_{t}-\right.$ $\left.E\left(\tilde{\pi}_{t}\right)\right]$ is, therefore, the unexpected rate of inflation with respect to the period ending at time $t$. Estimation results are also provided for this model with the constraint, $\beta_{3} \equiv 0.0$. Tilde $(\sim)$ denotes a random variable.

The lagged variable $\tilde{Y}_{t-1}$ was used in order to attack serial correlation problems that will be obvious from the estimation results presented below. Its introduction was not motivated by economic theory.

One of the subperiods considered here is 1929-46. In some cases, use of data for 1 year, 1946, seemed to dramatically affect the estimation results, at least relative to what was expected. Thus, estimation results were always obtained for the period 1929-45 and for the period 1929-46. I still do not know why 1946 occasionally had a seemingly important effect. The reason may turn on some quirk of the dataconstruction methods used by our sources of data. Or it may turn on interesting substantive issues, such as the September 1945 termination of the special war-time "emergency facilities" amortization program or the 1946 conversions of some fixed assets from so-called Government 
Owned but Privately Operated (GOPO) facilities to privately owned and privately operated facilities. (Pertinent remarks on the latter issue are provided by Gordon [1969]).

The following types of estimation results are given in each table: (1) the estimated value of $\beta_{i}$ and the corresponding $t$-statistic, for each $i$; (2) the estimated standard deviation, $\sigma_{\xi}$, of the disturbance, $\tilde{\xi}_{t}$; (3) the sample value of the adjusted coefficient of multiple determination, $\bar{R}^{2}$; (4) the standardized runs statistic, $z$, for the disturbance, $\tilde{\xi}_{t}$; and (5) the estimated value of the lag- $i$ serial correlation coefficient, $\rho_{i}$, of the disturbance, $\tilde{\xi}_{t}$ for lags $1-5$.

\section{Estimation Results}

\section{Effective Tax Rates}

A seemingly direct way of testing the tax-effects hypothesis is to assess the influence of inflation on various measures of real tax burdens. Conditional on a proportional income tax system, the tax-effects hypothesis predicts that aggregate tax liabilities will increase faster than the actual rate of inflation because taxable income is predicted to increase faster than this rate. This implies, in turn, that aggregate taxes will, for a given real output level, increase faster than before-tax net operating cash flows. Equivalently, the real rate at which these cash flows are taxed should be an increasing function of both the expected and the unexpected components of inflation. And the effect of each component should vary directly with the nominal tax rate as well as, for example, the capital intensity and "inventory intensity" of production.

Estimation results dealing with this issue are presented in table 1. Both the numerators and denominators used for the tax rates underlying this table are in current dollars. Thus, the tax rates are in real terms. The denominators are intended to be proxies for the before-tax cash payoff to capital, which is the pretax cash flow variable relevant to capital budgeting issues. Results are presented for total profits taxes, that is, federal, state, and local profits taxes.

For the overall period 1929-74, when $Y_{t-1}$ is excluded from the model, the estimation results seem consistent with the tax-effects hypothesis as far as the expected rate of inflation is concerned. As can be seen, this appears to be primarily attributable to the prewar period. Moreover, when $Y_{t-1}$ is included in the model, the results are consistent with $\beta_{1}=0.0$. In addition, contrary to the tax-effects hypothesis, the overall and prewar results appear inconsistent with a positive effect of the unexpected rate of inflation.

Also contrary to the tax-effects hypothesis is the apparent inconsistency between the estimation results and a positive effect of the ex- 


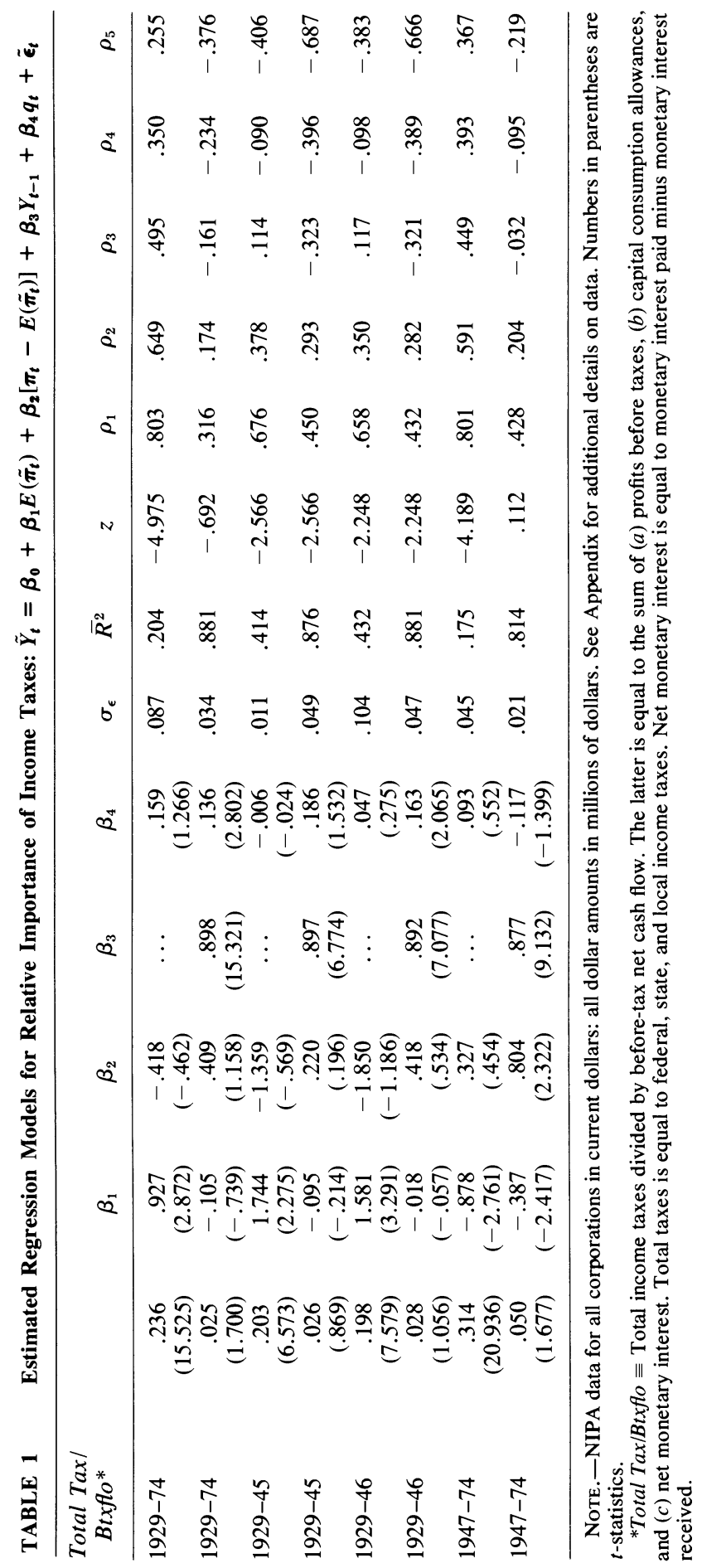


pected rate of inflation for the postwar period, 1947-74. For this period, nominal corporate income tax rates were, on average, above those prevailing over the $1929-46$ period.

For the postwar period, the importance of the unexpected rate of inflation seems to be critically dependent on whether $Y_{t-1}$ is included in our regression model. But even when $Y_{t-1}$ is included, the significance of the unexpected rate's influence does not seem to be overwhelming.

Another measure of the real tax burden is considered in table 2. This table deals with the tax component of the rental rate per unit of capital-in real terms. ${ }^{6}$ The tax-effects hypothesis predicts that this component's importance is an increasing function of each component of inflation, because aggregate nominal taxes should increase faster than the actual rate of inflation.

The estimation results presented in table 2 seem to tell the same basic story as that told by the results in table 1 . As far as the expected rate of inflation is concerned, the results for 1929-74 seem consistent with the tax-effects hypothesis-when the constraint $\beta_{3}=0.0$ is imposed. But this consistency appears to turn on the prewar data rather than the data for the higher nominal tax rate period 1947-74.

For the prewar period, the estimated value of $\beta_{2}$ has a sign inconsistent with the tax-effects hypothesis. In any event, the estimation results for $\beta_{2}$ seem inconsistent with statistical significance for this period as well as for the postwar period.

The estimation results for both $\beta_{1}$ and $\beta_{4}$ are clearly dependent on whether $Y_{t-1}$ is included in the model, at least for the prewar and overall periods. The point estimate and statistical significance of $\beta_{1}\left(\beta_{4}\right)$ decrease (increase) when $Y_{t-1}$ is included. But over the postwar period, the results for $\beta_{1}\left(\beta_{4}\right)$ are always consistent with $\beta_{1}=0\left(\beta_{4} \neq 0\right)$. Such differences between prewar and postwar results-which may be due to structural shifts-will also appear in results described later.

Results for a third measure of the real tax burden are presented in table 3. This measure pertains to total profits taxes per unit of aggregate domestic output (for all corporations), which is a proxy for total sales of current output. This measure is also in real terms. For a given level of output, the tax-effects hypothesis predicts that aggregate taxes should increase faster than the rate of inflation and that the rate of increase in total sales should be equal to the rate of inflation. Thus, the "tax-bite" per dollar of sales should be an increasing function of each component of the actual inflation rate. On balance, the results presented in table 3 are consistent with those described above.

Since the tax-effects hypothesis does not seem to identify dominant forces pertaining to profitability, one expects that it will not identify

6. Pertinent expressions for this rental rate are given in, e.g., Hall and Jorgenson $(1967,1971)$. 


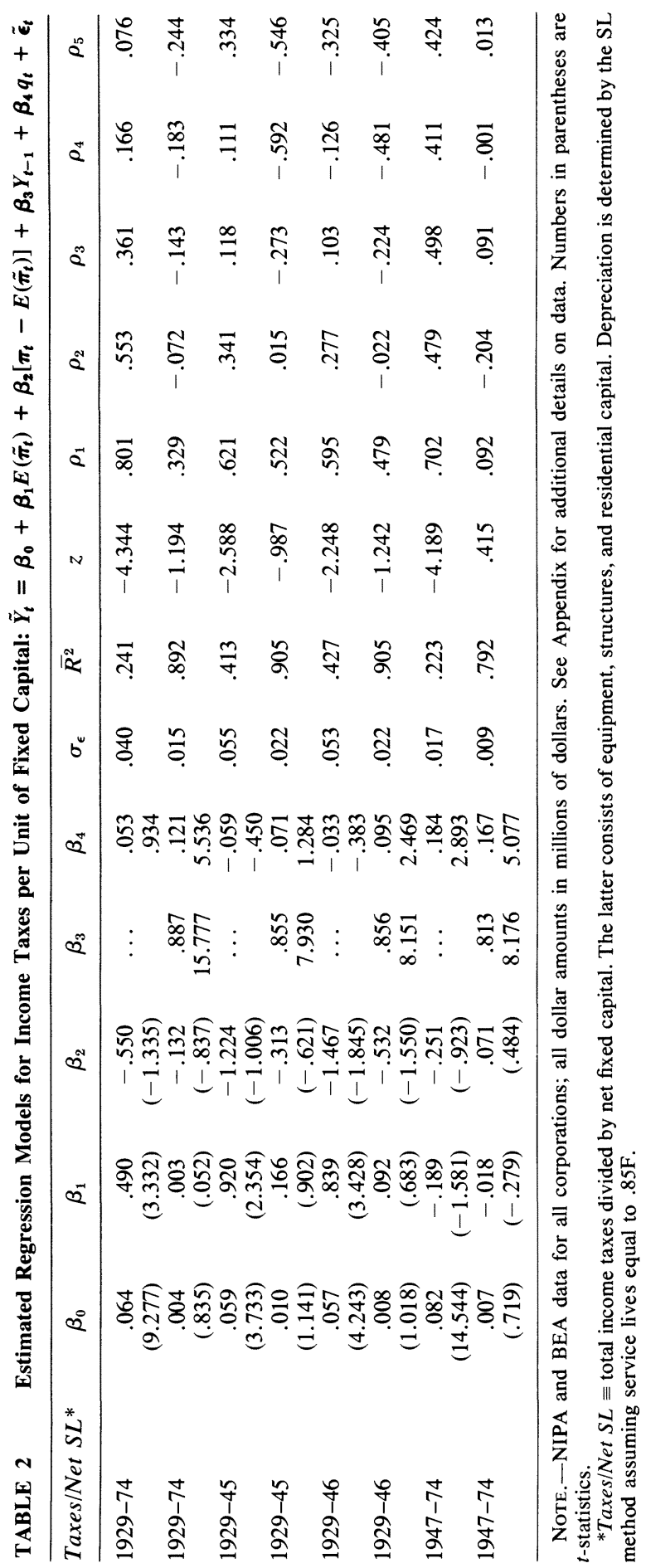




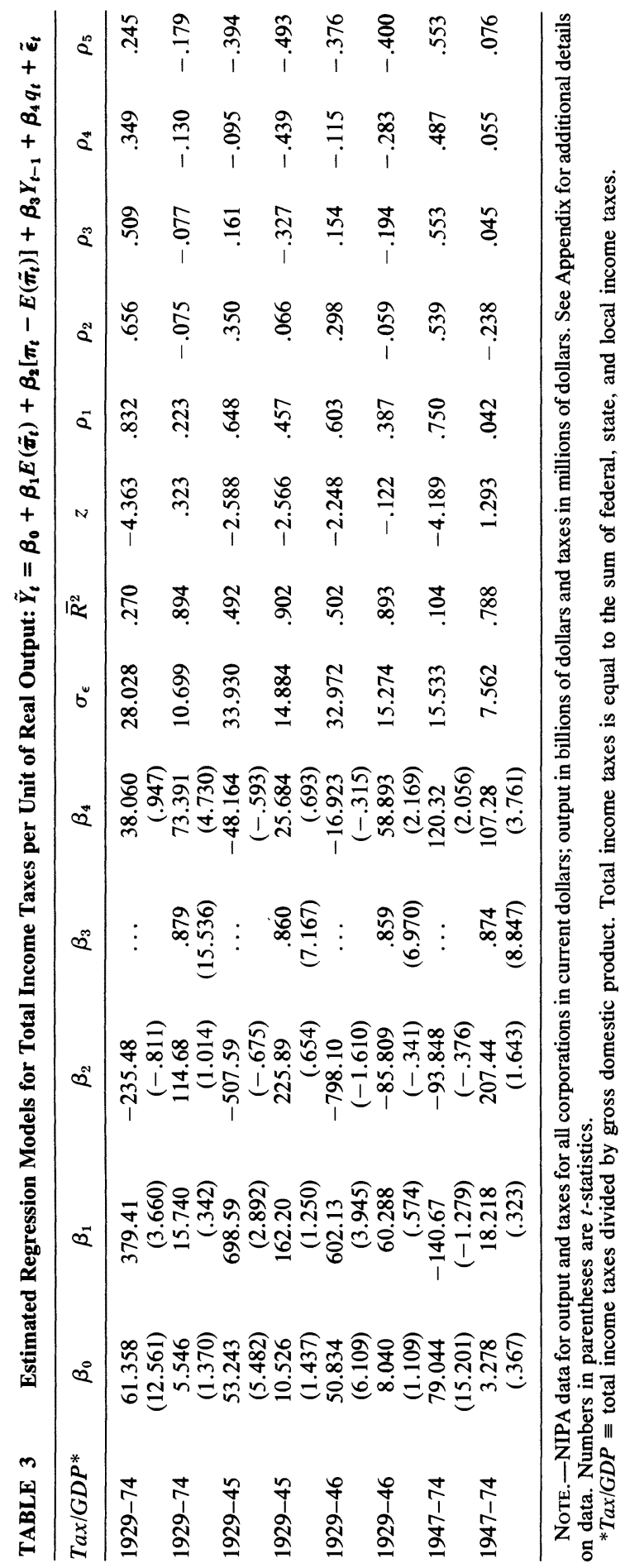


dominant forces pertaining to investment incentives. Results on the latter are presented in the next section.

\section{Rates of Investment}

There are, of course, various ways of measuring rates of investment in fixed capital. The results presented in tables $4-8$ are based on several different approaches. Each one deals with a different aspect of investment behavior, but they all seem to "tell the same story.",

The results presented in table 4 pertain to the rates of growth in fixed capital implied by capital expenditures, for net fixed capital conditional on straight-line (SL) depreciation and service lives equal to 85 percent of those specified in the 1942 edition of the IRS's Bulletin $F$, henceforth referred to as $.85 \mathrm{~F}$ service lives (U.S. Department of the Treasury, Internal Revenue Service 1942). Data for gross capital and for different service-life assumptions led to essentially the same results, as did data based on double-declining balance (DDB) depreciation; SL and DDB are the two methods for which BEA data are available.

Both the numerators and denominators used for the investment rates for period $t$ are in terms of the period $t$ price level. Thus, the rates are in real terms. There is, of course, some measurement error here and for other variables based on the same denominators. Some sort of average of beginning of period and end of period capital stock data might be more appropriate. But experimentation along these lines seemed to lead nowhere. ${ }^{7}$

The tax-effects hypothesis implies that the expected value of the rate of capital expenditure conditional on the expected rate of inflation is decreasing in the latter expected rate. The estimation results conditional on the constraint $\beta_{3}=0.0$ are inconsistent with this for the overall period, 1929--74, and for both the prewar and postwar period and for investment rates based on both gross fixed capital and net fixed capital. When $Y_{t-1}$ is allowed to enter with a nonzero coefficient, the results are still inconsistent with the tax-effects hypothesis.

Note that the value of $\tilde{R}_{K t}$ is not the value of the total return per unit negative effect of $E\left(\tilde{\pi}_{t}\right)$. They are, at least for the 1929-74 and 1929-46 periods, consistent with a positive effect. The lower nominal tax rate and the lower expected rates of inflation that prevailed during the prewar period-relative to 1947-74-may be important reasons for this.

On balance, the unexpected component of the inflation rate seems to have no important effect on the expected rate of investment. This

7. "Constant-dollar' data could also be used to define real rates, but such data were not available for all the series and years of interest here (e.g., constant-dollar Gross Domestic Product for all pre-1947 years). So long as our exploratory analyses did not imply that the choice of data type made an essential difference, we chose to use current-dollar data when available. 


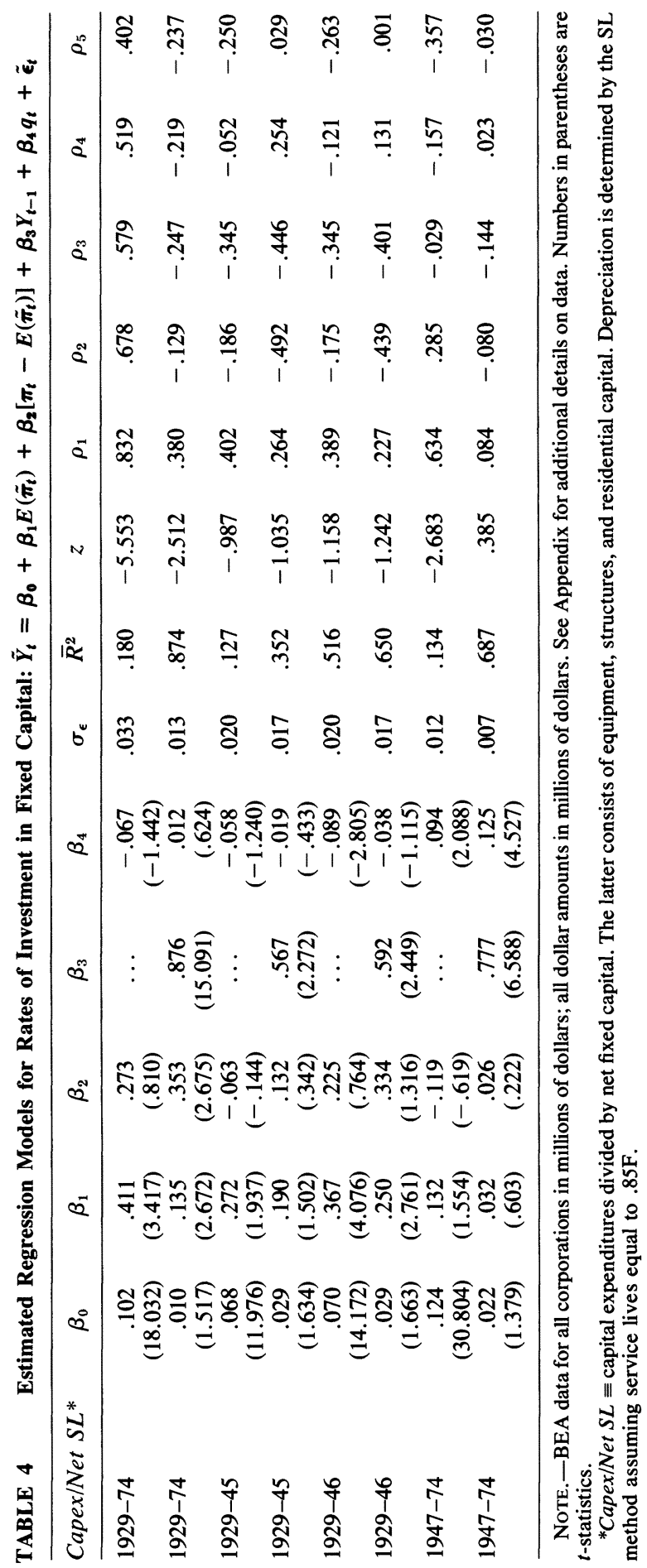




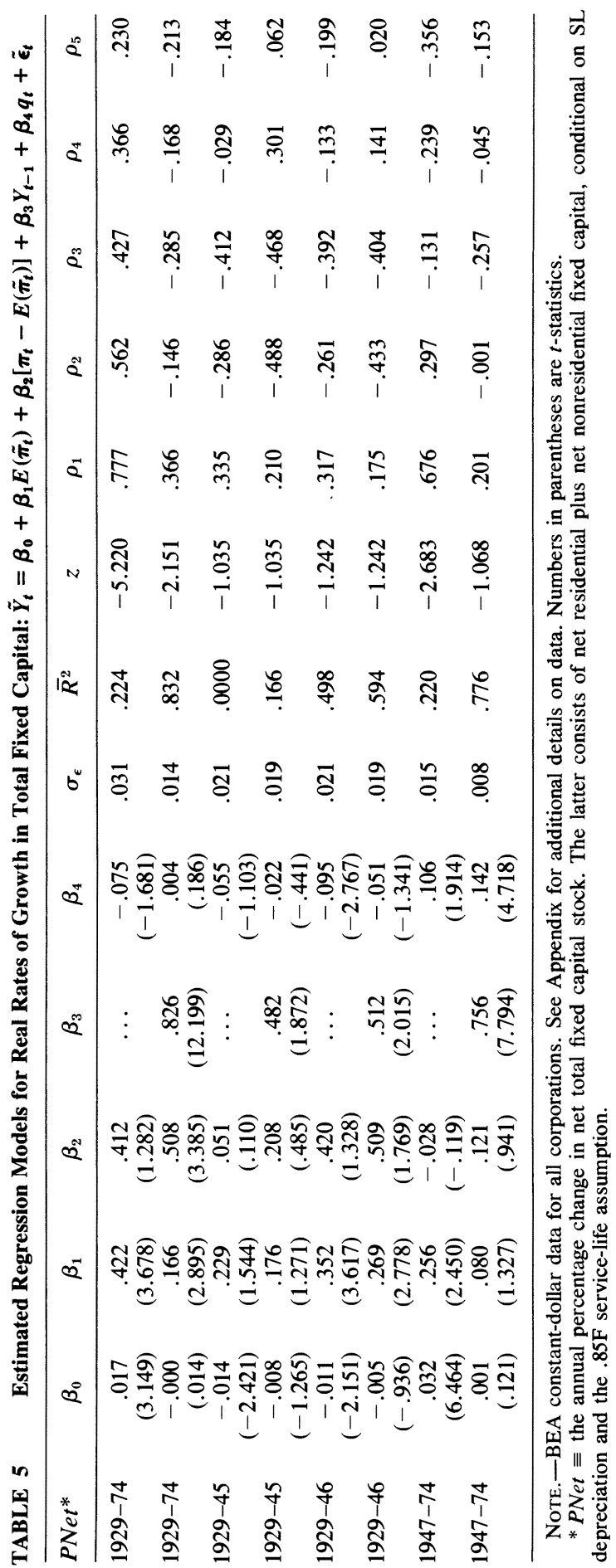




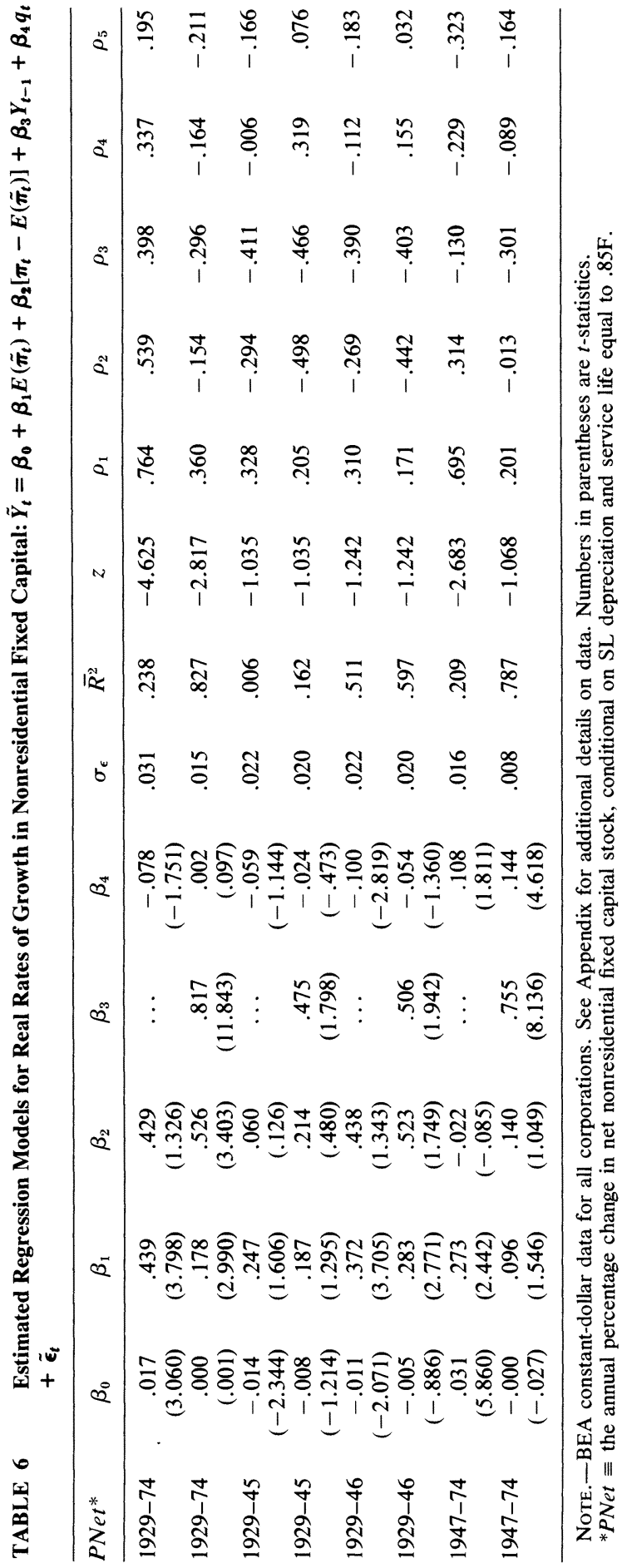




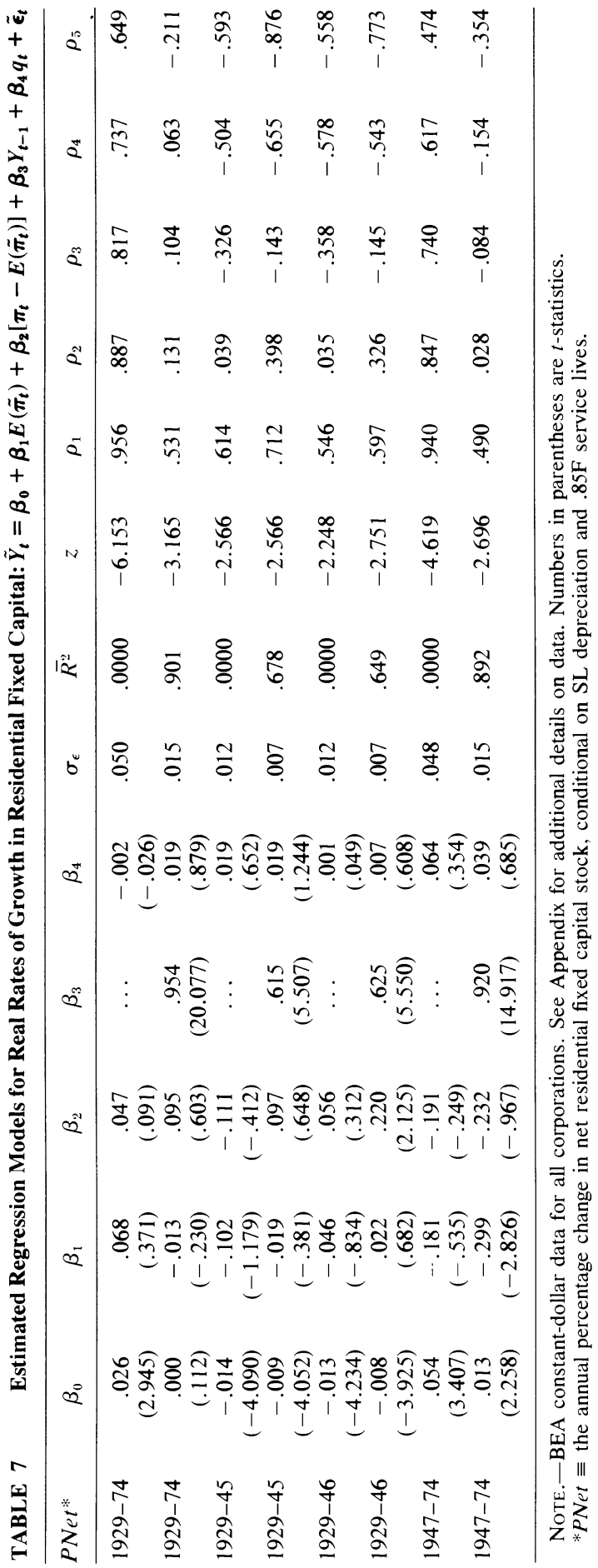




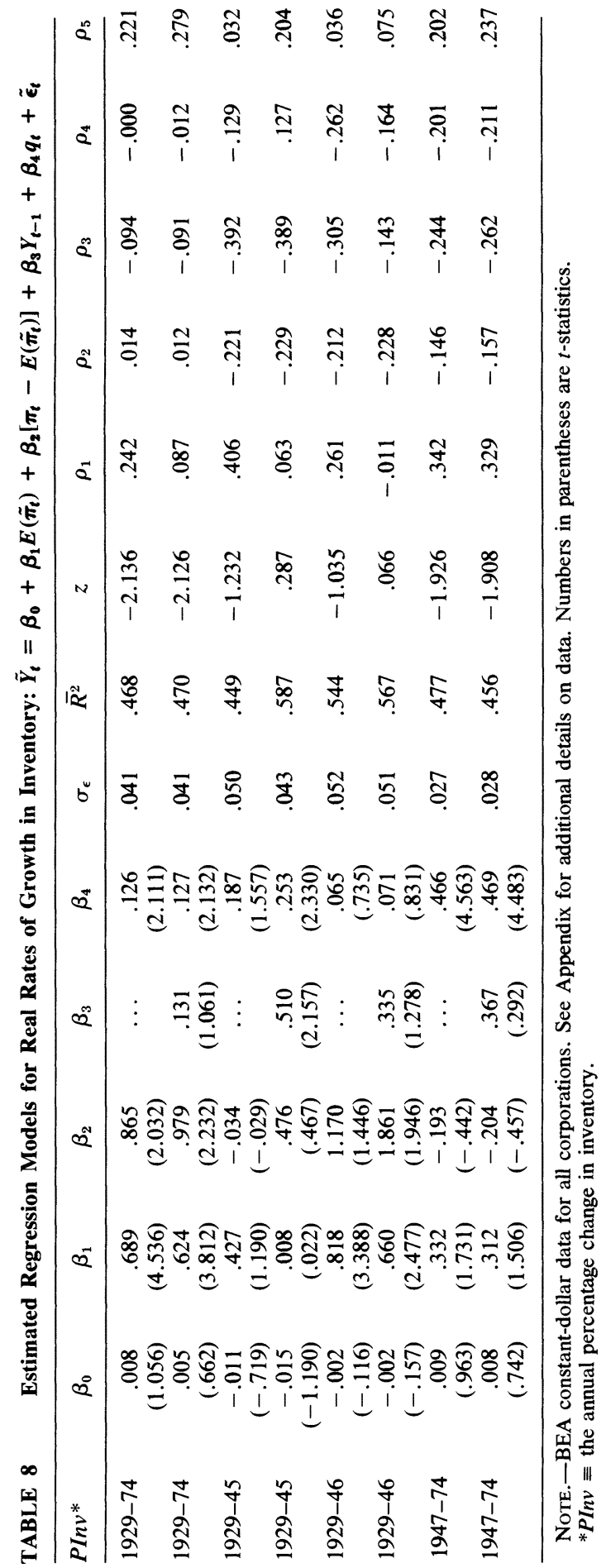


seems plausible. Unanticipated events of period $t$ should have no systematic effect on investment rates chosen during period $t$.

Of course, capital expenditure rates pertain to gross investment expenditures. These rates are not, therefore, adjusted for "outflows" of units of capital due to depreciation or sales. The capital expenditure rates for period $t$ are valuable sources of information because they pertain to commitments made during the current period. But one can argue that these rates are chosen to attain desired net investment rates.

To get some insights on net investment, one can look at results based on the rates of growth implied by successive values of capital stock. Such results are presented in tables 5-7. The data used for these tables are constant-dollar data. Hence, the growth rates underlying these tables are in real terms.

Table 5 provides results on total capital stock, which equals residential plus nonresidential fixed capital. The residential component is based on SL depreciation and the $.85 \mathrm{~F}$ service-life assumption. (For residential capital, data based on different depreciation methods and service lives are not available from the BEA data file.) If the implications of the tax-effects hypothesis are descriptively adequate, the real rates of growth in total fixed capital should vary inversely with $E\left(\tilde{\pi}_{t}\right)$.

As can be seen from table 5, the behavior of total fixed capital is inconsistent with the tax-effects hypothesis. Indeed, for the overall period, 1929-74, and for some of the subperiods, the estimation results for $\beta_{1}$ are consistent with a significantly positive value.

Tables 6 and 7 provide results for nonresidential and residential capital, respectively. The results for nonresidential fixed capital are substantially consistent with those for total fixed capital, probably because nonresidential fixed capital is the dominant component of the total. For the most part, the results for residential fixed capital are consistent with a value of $\beta_{1}$ that is insignificantly different from zero. Thus, these results are also inconsistent with the tax-effects hypothesis, which implies $\beta_{1}<0.0$.

As can be seen from the postwar results with $\beta_{3}$ not constrained to equal zero, the results for residential capital are not completely inconsistent with the tax-effects hypothesis. For this subperiod, the results for $\beta_{1}$ are consistent with $\beta_{1}<0.0$. The difference between these results and those for nonresidential capital may be due to the alleged differential effects of macroeconomic stabilization policies on construction activities. In any event, the fact the $\beta_{1}<0.0$ is not inferred for nonresidential capital too implies that the tax-effects hypothesis, by itself, is not descriptively adequate.

Table 8 provides results on another aspect of investment incentives, namely, the real rate of growth in inventory. When expected rates of inflation are positive, the tax-effects hypothesis implies that incentives 
to invest in inventory will be adversely affected, too, because of the joint effects of historical cost accounting methods and positive expected rates of inflation. As can be seen from table 8 , the estimation results for $\beta_{1}$ appear inconsistent with $\beta_{1}<0.0$ and, thus, inconsistent with the tax-effects hypothesis.

On balance, the results in tables 5-8 pertaining to $\beta_{2}$ do not suggest that the unexpected component of inflation has a systematic important influence on rates of growth in fixed capital or inventory. This seems plausible. One should not expect investment decisions to be affected by unanticipated events.

Nor should one overlook the limitations of our results. The influence of 1 year's data, namely, those for 1946 , is quite puzzling. So is the seemingly erratic influence of the rate of change in industrial production. Whether these mysteries are induced by inadequacies in our data or in our models is still not clear on the basis of the results presented here or unreported results. Nevertheless, the inconsistencies between all of the results presented thus far and the tax-effects hypothesis seem too consistent to be attributable to these puzzles. The results presented below provide additional support-albeit indirect-for the crux of our inferences, and they point to some possible reasons for the inadequacy of the tax-effects hypothesis.

\section{Tax Shield Provided by Interest Deductions}

The major predictions of the tax-effects hypothesis turn on firms' not being permitted to deduct, for tax purposes, the current values of the services of factors of production used during a given period. The services provided by units of depreciable capital and units of inventory are of particular interest here. This predicament is, of course, a major feature of a tax system based on historical cost accounting methods, and it is the feature that indexation is supposed to eliminate.

But explicit indexation may not be necessary to achieve all the effects of indexation. The same effects can be attained, at least with respect to expected rates of inflation, if nominal interest rates incorporate unbiased forecasts of rates of inflation. (Nominal interest rates set when debt is issued cannot, by themselves, take unexpected rates of inflation into account.) If they do, then financing acquisitions of factors' services with debt-on which interest expense is tax deductible-provides a means of getting a tax deduction for the expected value of the difference between historical costs and current costs per dollar of debt-financed outlay for factors of production. Presumably, prevailing nominal interest rates are also incorporated into the costs of acquisitions made via "noninterest-bearing" trade credit, which affect, in turn, tax-deductible "costs of goods sold" and other factor costs. Thus, the use of debt-bearing explicit interest 
charges does not seem essential for hedging against expected rates of inflation. ${ }^{8}$

The results presented in table 9 deal with the extent to which firms alleviated the expected tax effects of inflation via the use of debt. Two different interest expense variables are used here. In the upper panel, interest expense is adjusted for the interest imputations made in the NIPA accounts. Since these imputations are not directly taxed, this variable does not seem to be precisely what we want. But it is an interest expense variable often used in works relying on NIPA data (see, e.g., Holland and Myers 1977) and it is a variable for which data (for "all corporations"') are available for the prewar period. Data on the seemingly more appropriate variable, net monetary interest, are only available for the postwar period. Results based on this variable appear in the lower panel of table 9 .

The fact that the NIPA imputations are appropriately disregarded when measuring tax shields is not the only reason for favoring, on grounds of principle, the net monetary interest variable. When the net interest variable is used to measure the debt-induced tax shield against expected inflation, double counting is a result. In the NIPA accounts, imputed interest is presumed to be paid by financial businesses to nonfinancial businesses, individuals, and governmental units in order to account for financial services for which no explicit charges are made. If nonfinancial businesses (the only potential recipients relevant here) really do receive such services, presumably the total explicit costs of the productive factors used is less than it would otherwise be. Thus, if the NIPA imputations are allowed to lower nonfinancial business interest cost, there should be a simultaneous upward adjustment in the total explicit cost incurred for so-called financial services. Presumably, the latter additional explicit costs would be tax deductible. Thus, not making this upward adjustment double counts the imputations that distinguish the NIPA accounting system's net interest variable from its net monetary interest variable.

Nevertheless, the data for both variables seem to tell the same story over the postwar period, as far as the results presented in table 9 are concerned. I shall therefore assume that net interest is an adequate

8. This argument does not imply that any issuer of debt is "gaining" at the expense of debt holders. When nominal interest rates increase to take account of expected rates of inflation, issuers get an implicit tax deduction for the expected effects of inflation. But, other things equal, the changes in nominal rates imply changes in the nominal income and, thus, tax liabilities of debt holders. Presumably, debt holders (in the aggregate) take their expected changes in tax liabilities into account when equilibrium nominal interest rates are set (along the lines described by Miller [1977]). When applied to the issues at hand, Miller's framework implies that, in equilibrium, no individual firm will be motivated to alter its financing decisions, given its production-investment decisions. This does not imply the absence of adjustments by firms in the aggregate, in response to, e.g., unanticipated shocks that disturb attained equilibria. Our results, which are based on aggregate data, necessarily deal with aggregate responses. 


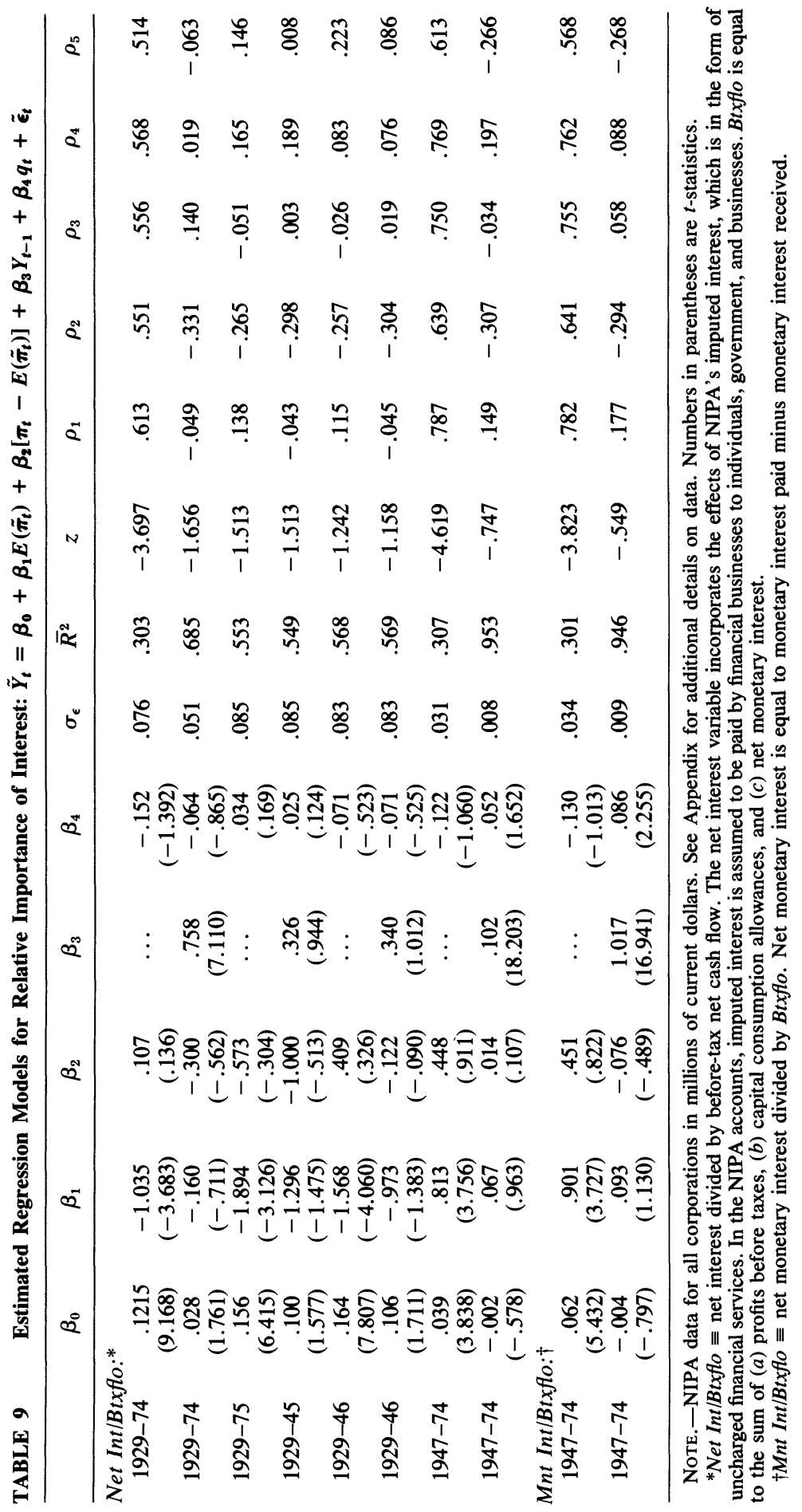


proxy for net monetary interest for the other time periods considered here.

The interest/cash-flow variable used for table 9 is a measure of the relative importance (in real terms) of the tax shield provided by debtbearing explicit interest charges. (Reliance on this measure presumes that the net shield provided by noninterest-bearing debt is equal to zero for the corporate sector as a whole.) This ratio should be an increasing function of the expected rate of inflation if it is to offset, at least in part, the increasing real rate of taxation induced by the joint effects of price level changes and a proportional tax system based on historical cost accounting methods. Since nominal interest rates are not expected to incorporate unanticipated inflation, the conditional expected value of our interest/cash-flow variable should be unaffected by $\left[\tilde{\pi}_{t}-E\left(\tilde{\pi}_{t}\right)\right]$. The results for all periods are consistent with this implication.

Insofar as the expected rate of inflation is concerned, our results for the postwar period are consistent with the predicted positive value for $\beta_{1}$ when $Y_{t-1}$ is not in our regression model. The statistical significance implied by our results disappears, however, when $Y_{t-1}$ is allowed to enter with a nonzero estimated coefficient. But during the prewar period, the results for $\beta_{1}$ are consistent with a nonpositive value of $\beta_{1}$. The shift from a prewar nonpositive value to a postwar value that is at least nonnegative is a shift in the "right direction," in the sense that it is consistent with a relatively greater use of the debt-induced tax shield during the higher nominal tax rate (and higher inflation rate) period. Such a shift may provide part of the explanation for the apparent descriptive inadequacy of the tax-effects hypothesis. Specifically, such a shift is consistent with firms' adopting, and the tax authorities' permitting, actions that serve to alleviate the higher real tax burdens that would otherwise prevail.

It is, perhaps, worth noting that the results for our net interest variable were among the few that were seriously affected by introducing the industrial production variable into our model. When the constraint $\beta_{4}=0.0$ was in force, the prewar results for $\beta_{1}$ were always substantially consistent with a significantly negative value, whether or not $Y_{t-1}$ was allowed to have a nonzero coefficient. When the percentage change in industrial production was included in our model, the estimation results for $\beta_{1}$ became quite dependent on whether $Y_{t-1}$ was included in our model-for reasons that are not obvious to me.

\section{Capital Gains on Fixed Capital and Inventory}

This induced increase in real tax rates can also be alleviated by positive real capital gains on fixed capital and inventory-two types of assets presumed to be of special importance by the tax-effects hypothesis. This hypothesis predicts, for example, that unanticipated increases in the expected rate of inflation will lead to windfall-type capital losses, 
because such increases are equivalent to unanticipated increases in real rates of taxation. And, of course, positive constant expected rates of inflation imply positive expected rates of change in real tax rates. The implications of these inflation-induced increases in expected real tax rates would be substantially weakened if, contrary to the tax-effects hypothesis, nominal capital gains were positively associated with the expected rate of inflation, implying that the expected capital gain varies directly with the expected rate of inflation. More generally, holdings of units of fixed capital and of units of inventory would both be complete hedges against expected (unexpected) rates of inflation if, for each type of asset, $\beta_{1}=1.0\left(\beta_{2}=1.0\right)$.

The data on nominal capital gains were obtained as follows. Consider, for illustrative purposes, units of capital stock on hand at time $t-1$. Let $\tilde{r}_{d t}$ denote the percentage change in the number of units of capital stock (i.e., depreciation or appreciation in real terms) per unit of capital stock on hand at time $t-1$. If the productivity of the capital stock is proportional to the number of units, $\tilde{r}_{d t}$ is the rate of real economic depreciation when $\tilde{r}_{d t}<\mathbf{0 . 0}$.

The nominal capital gain, from $t-1$ to $t$, per unit of capital stock on hand at time $t-1$ is equal to

$$
\tilde{R}_{K t}=\left(1+\tilde{r}_{P t}\right)\left(1+\tilde{r}_{d t}\right)-1.0,
$$

where $\tilde{r}_{P t}$ is the rate of change in the price of a unit of capital stock.

The values of $\tilde{r}_{P t}$ and $\tilde{r}_{d t}$ can be obtained from our BEA data on the current value and constant value of fixed capital. Let $\tilde{P}_{t}$ denote the price per unit of capital at time $t$; let $\tilde{K}_{t}$ denote the number of units on hand at time $t$, and let $t=0$ denote the "base year" used for constantdollar data. The current-dollar and constant-dollar values of the net fixed capital stock at time $t$ are, therefore, given by $\tilde{P}_{t} \tilde{K}_{t}$ and $P_{0} \tilde{K}_{t}$, respectively. Using these values, for time $t-1$ and time $t$, one gets

$$
\tilde{r}_{P t}=\frac{\tilde{P}_{t}}{\boldsymbol{P}_{t-1}}-1.0=\frac{\left(\tilde{P}_{t} \tilde{K}_{t}\right) /\left(P_{0} \tilde{K}_{t}\right)}{\left(P_{t-1} K_{t-1}\right) /\left(P_{0} K_{t-1}\right)}-1.0,
$$

and

$$
\tilde{r}_{d t}=\frac{\tilde{D}_{t}}{K_{t-1}}=\frac{P_{0} \tilde{D}_{t}}{P_{0} K_{t-1}}
$$

where $\left(P_{0} \tilde{D}_{t}\right)$ is the constant-dollar value of depreciation for the period $t-1$ to $t ; \tilde{D}_{t}$ is, therefore, the implied total loss of units of productive capacity.

Note that the value of $\tilde{R}_{K t}$ is not the value of the total return per unit of capital over the period $t-1$ to $t$, because it does not incorporate a measure of the real output per unit of capital stock. The latter variable is a flow component of the total return to capital, which is implied by 
use of this factor of production. This component is, in effect, analogous to the dividend component of the total return on common stock. And the value of $\tilde{R}_{K t}$ is analogous to the conventional capital gain component. We shall deal with the output (or flow) component in the next section.

Estimation results for capital gains rates are presented in tables 10 and 11. Table 10 presents results for fixed nonresidential capital conditional on the SL depreciation method. Results based on the DDB method led to essentially the same inferences. So did results for different service-life assumptions. Only results for service lives equal to $.85 \mathrm{~F}$ are presented here. Table 11 provides results for residential capital and for inventory. For inventory, $\tilde{r}_{d t} \equiv 0.0$ for each $t$. The results for residential capital are also based, as before, on the SL depreciation method and the $.85 \mathrm{~F}$ service-life assumption.

The results for fixed nonresidential capital are consistent with a positive effect of expected inflation on the conditional expected value of the capital gains rate. For the postwar period, the results for $\beta_{1}$ and $\beta_{2}$ are substantially consistent with $\beta_{1}=1.0$ and $\beta_{2}=1.0$ when $Y_{t-1}$ is not in the model. When it is in, the results are still quite consistent with $\beta_{2}=1.0$ but not with $\beta_{1}=1.0$. Since $\tilde{Y}_{t-1}$ and $\tilde{E}\left(\tilde{\pi}_{t}\right)$ are positively correlated, the apparent dependency between the estimated values of $\beta_{1}$ and $\beta_{3}$ should not be surprising. Of course, since both $\tilde{Y}_{t-1}$ and $\tilde{E}\left(\tilde{\pi}_{t}\right)$ are positively serially correlated, the positive covariation of $Y_{t-1}$ and $\tilde{E}\left(\tilde{\pi}_{t}\right)$ may be "spurious," in the sense described by Granger and Newbold (1974). In any event, it does seem that fixed nonresidential capital served as at least a partial hedge against both components of inflation.

The results for residential capital are roughly the same as those for nonresidential fixed capital, particularly for the postwar period. The results for inventory are quite different. Inventory always seems to provide more than a complete hedge against the unexpected component of the inflation rate. And for at least the overall and postwar periods, it seems to be at least a complete hedge against the expected component. Both of these features of inventory holdings would have alleviated the adverse predictions of the tax-effects hypothesis with respect to firms' posttax real profitability.

\section{Real Output Rates}

Results for proxies for the flow component of the return to total fixed capital plus inventory are described in table 12. The "cash flow" and "total profits tax" data used for table 12 are identical to those used before. The denominators used for this table were computed using our BEA data on total fixed capital (i.e., residential plus nonresidential fixed capital) and on inventory holdings. The numerators and denominators used here are both in terms of current dollars. Thus, the computed output rates are in real terms. 


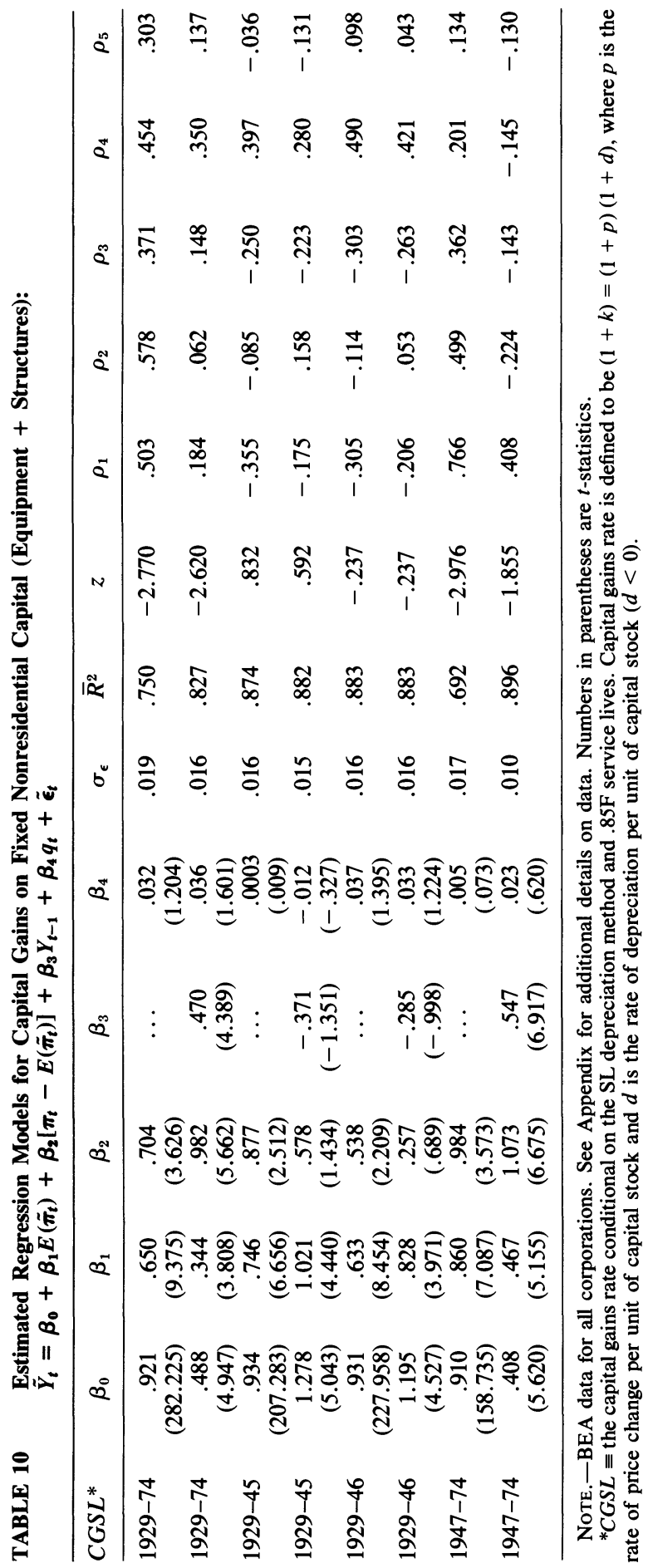




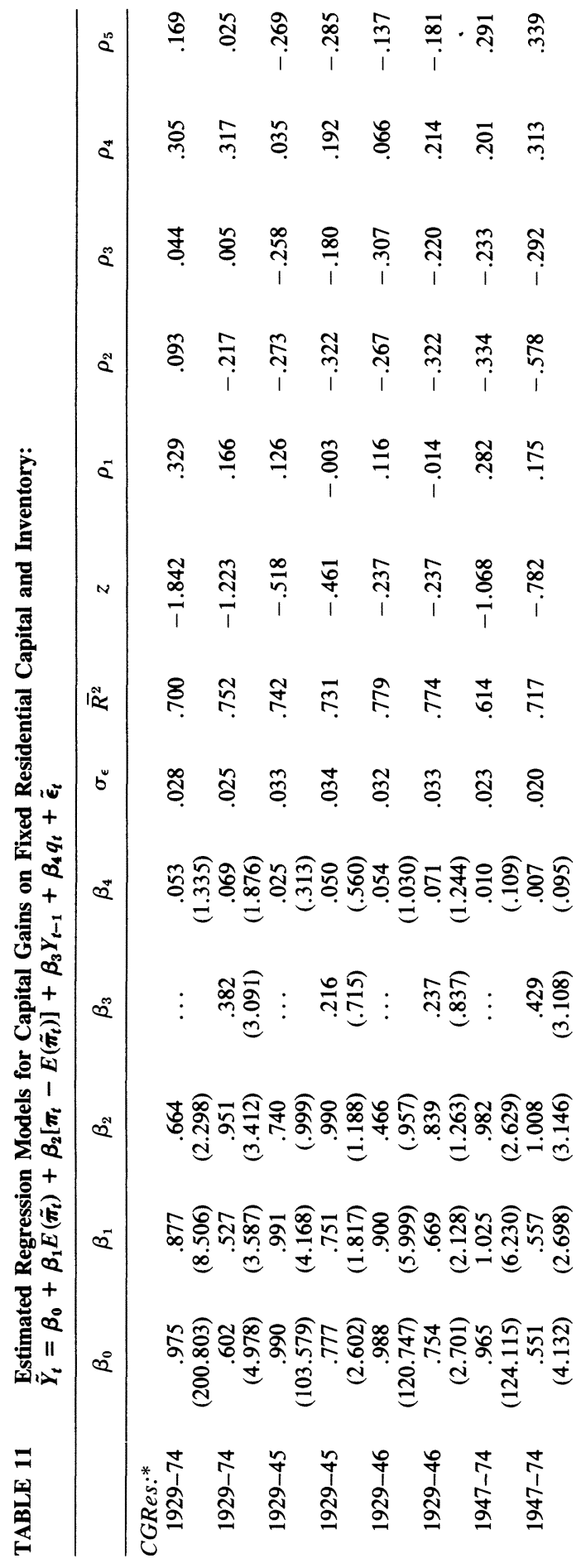


ஜํำ

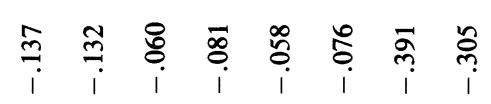

倳

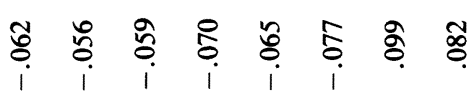

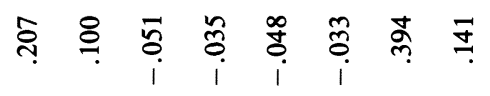

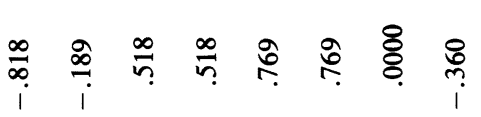

… సี.

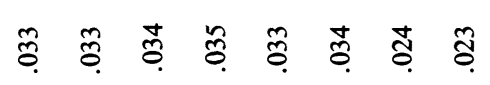

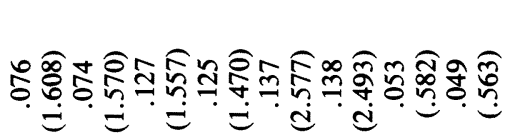

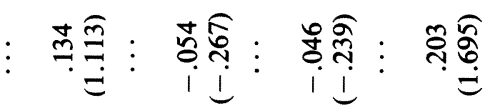

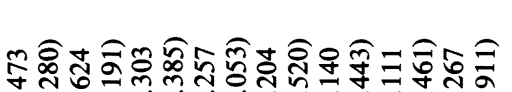

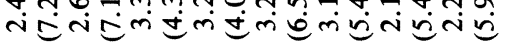

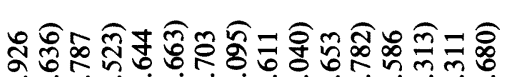
它 过 过

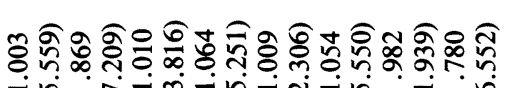
-

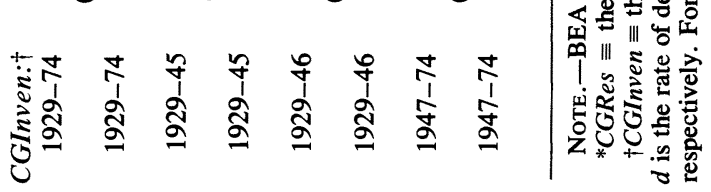




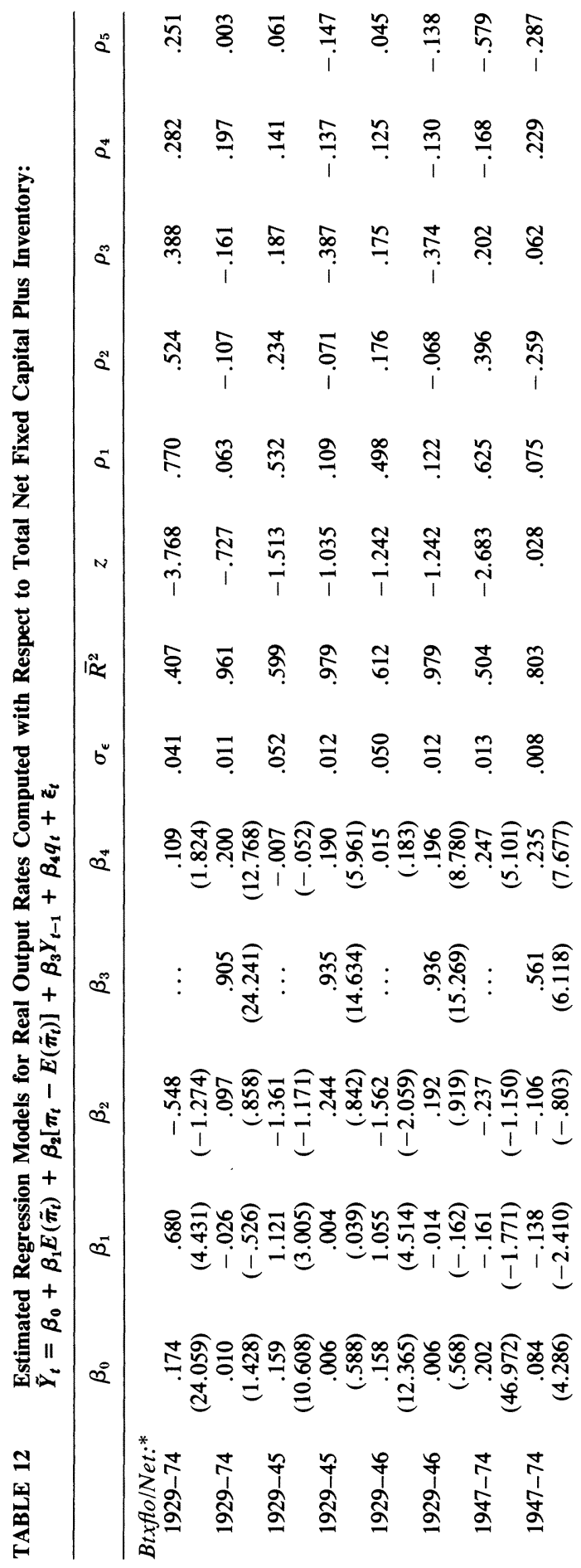




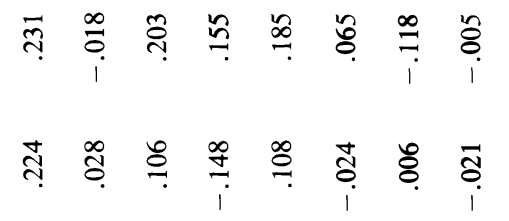

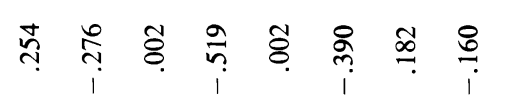

ఫึ?

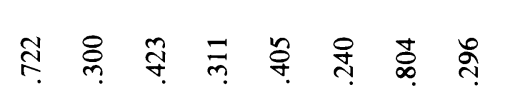

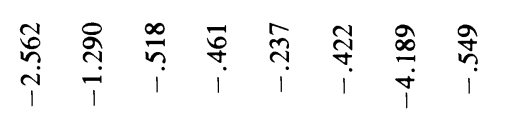

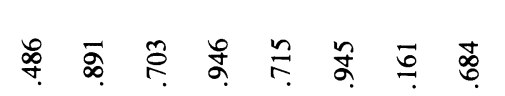

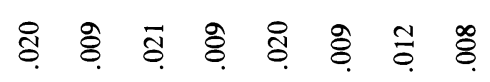

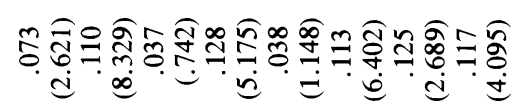

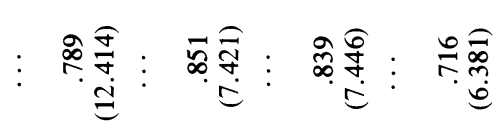

กิ

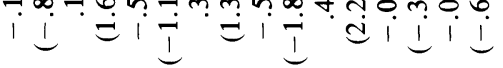

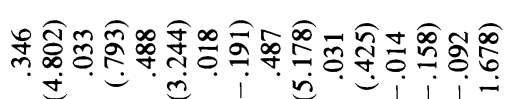

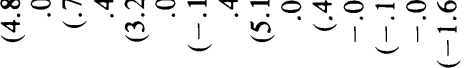

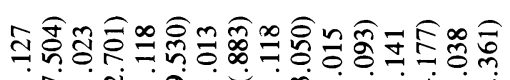
हु

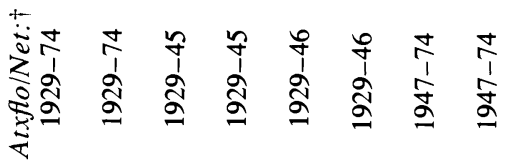

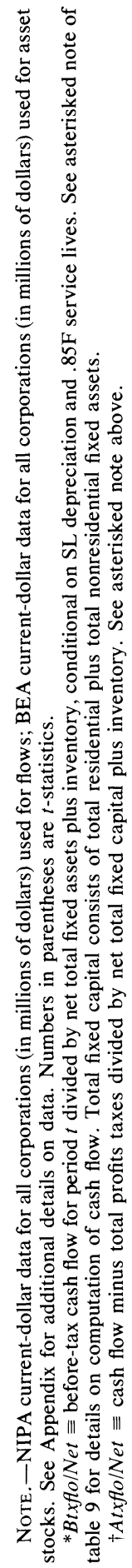


Given the previously discussed results on capital gains, the results in table 12 would be inconsistent with the adverse predictions of the tax-effects hypothesis if they are consistent with real output rates that are at worst unaffected by either component of inflation. In this case, the inferences made earlier about capital gains would apply to total periodic returns, too.

On balance, the results in table 12 , for both after-tax and before-tax net operating cash flows, are basically consistent with nonnegative values of both $\beta_{1}$ and $\beta_{2}$. And in some cases the results are consistent with significantly positive values of $\beta_{1}$. These results are conditional on SL depreciation and $.85 \mathrm{~F}$ service lives. Different depreciation methods and service-life assumptions led to essentially the same results.

The only seemingly important inconsistency with $\beta_{1} \geqslant 0.0$ appears in the before-tax real output rate for the postwar period. But this is contrary to the tax-effects hypothesis, in its pure form, because it pertains to before-tax, not after-tax, returns. The before-tax real returns are not predicted to be increasing functions of either component of inflation by that hypothesis. Indeed, it predicts constant before-tax real returns (conditional on an output level) and decreasing after-tax real returns.

The difference between the data used for the top and bottom panels of table 12 is due to the adjustment for total profits taxes. Taken at face value, the results in table 12 for the postwar before-tax returns are consistent with the statement that inflation is a proxy for "business conditions" and that positive expected rates of inflation are "bad for business.' The corresponding after-tax results are consistent with the tax system's alleviating the effects of adverse business conditions.

\section{Remarks on the Descriptive Inadequacy of the Tax-Effects Hypothesis}

\section{Tax Code Issues}

Our results are consistent with the existence of forces that at least alleviated the effects predicted by the tax-effects hypothesis, particularly with respect to the postwar period. Changes in the income tax code (or its application) that had the same ultimate effect that formal indexation would have had can induce such forces. Changes in the code (or its application) consistent with this "indirect indexation" perspective could involve, for example, increasing (decreasing) allowable service lives on depreciable assets and liberalizing (restricting) conditions under which accelerated depreciation methods could be used during and after periods of inflation (deflation). An examination of the parts of the federal income tax provisions pertaining to depreciation suggests that such changes did take place, especially when one com- 
pares the primarily inflationary postwar period with the prewar period, which encompasses several deflationary periods. ${ }^{9}$

During the prewar period, the changes that took place seemed to be in the direction of reducing firms' latitude of choice. For example, the various editions of Bulletin $F$-which supplied guideline service lives for depreciable assets-seemed to have been motivated by such an objective. The first edition of Bulletin $F$, published in 1920, appeared willing to rely upon "prevailing business practices," without supplying any data-based guidelines. The next edition, published in 1931 (after some nontrivial price-level declines), was accompanied by a document entitled Preliminary Report on Depreciation Studies, which stipulated the "probable useful life" and the corresponding SL depreciation rate for each of 2,700 different kinds of industrial assets. The third edition of Bulletin $F$, published in 1942, also specified guideline service lives, but for 5,000 different types of assets (see U.S. Department of the Treasury, Internal Revenue Service 1942).

Changes in the direction of restrictiveness are also implied by the informational and "burden-of-proof" demands placed on taxpayers. Treasury Decision 4422 (which constituted an amendment to existing regulations) is illustrative in this regard. Evidently IRS inferred, on the basis of its own studies, that the depreciation deductions taken by many firms had been "excessive," in the sense that continued application of past depreciation methods would lead to "fully depreciated assets" before the assets' useful lives were attained. As a result, the Treasury seemed to want to reduce depreciation taken in future years to the extent that it was thought to be excessive in the past. This supposedly constituted important motivation for Treasury Decision 4422 (issued in February 1934).

This decision made three important changes: (1) It required that taxpayers supply detailed schedules of information to be used in substantiating depreciation deductions. (2) It required that all future depreciation charges be limited to what would be needed to recover undepreciated balances over assets' remaining useful lives. (3) It placed the burden of justifying depreciation deductions on taxpayers. Before this change, a deduction could not be disallowed unless IRS could show-with "clear and convincing evidence" — that a deduction claimed by a taxpayer was unreasonable.

Developments with respect to depreciation methods seemed to have been consistent with moves toward greater restrictiveness over the prewar period. No taxpayer was required, as a matter of law, to use any particular methods. But for the pre-1945 years, the SL method

9. The discussion provided below draws heavily on the following: Montgomery (1917, 1936); Montgomery, Taylor, and Richardson (1946, 1947); Grant and Norton (1955); McCarthy (1968, 1974); Coughlan and Strand (1969); Mertens (1973); and Commerce Clearing House (1978). 
seemed to be the only one to which IRS gave (at least unofficial) prior approval. (In general, the acceptability of all accounting methods depends on the IRS commissioner's approval.) It is, for example, the only method explicitly mentioned in the 1931 edition of Bulletin $F$ and IRS's Mimeograph 4170 issued on April 4, 1934. Pronouncements with respect to the declining-balance method seemed to reflect this IRS position. In 1927, it ruled that neither approval nor disapproval of the declining-balance method would be given in advance of an audit of a taxpayer's annual return. This ruling was not officially modified until 1946, when IRS ruled that it would approve of the declining-balance method's use in advance of an audit if this method "accords with the method of accounting regularly employed in keeping the books of the taxpayer'; in another 1946 ruling, it limited the rate used under the declining-balance method to a maximum of $150 \%$ of the SL rate that would otherwise be appropriate. ${ }^{10}$ The positions adopted by the Treasury in cases that went before the tax court in the pre-1946 period are consistent with an intention of restricting the use of the decliningbalance method.

Developments during the war period (e.g., the provisions regarding emergency facilities and the capital gains/losses treatment of gains and losses on property used in a trade or business) and developments during the postwar period seemed to reflect a different attitude. For example, the Internal Revenue Code of 1954 provides advance approval of two basic accelerated methods: the sum-of-the-years' digits method and the declining-balance method, with the rate used for the latter limited to twice the appropriate SL rate computed without regard to salvage value. Advance approval of the SL method was also reiterated. (These provisions applied to post-1953 acquisitions.)

In 1962, a revised edition of Bulletin $F$ was published. This edition provided guideline lives for classes of assets (rather than for specific items). These suggested lives were claimed to be $30 \%-40 \%$ shorter than those provided in the earlier (1942) edition of Bulletin $F$. In addition, a so-called reserve ratio test was specified, which could have been used to justify even shorter lives. (Justification based on "all the facts and circumstances" was, in general, also still available.) When it appeared that many firms would fail the reserve ratio test, the test was changed in 1965 (via Revenue Procedure 65-13)!

10. Advance approval of the declining balance method was via U.S. Department of the Treasury, Internal Revenue Service (1946-52), p. 42. The origin of the "official" maximum rate (under DDB) equal to $150 \%$ of the normal SL rate seems to have been a 1946 special ruling dealing with rental housing (see Montgomery et al. [1947], p. 875). Finally, note that a tie-in between tax reporting and financial reporting is usually associated with adopting the LIFO inventory method for tax reporting. Thus the first 1946 ruling regarding depreciation methods surprised me. 
Around 1971, it appeared that the modified reserve ratio test would still not be passed by many firms. This is the setting that led, in part, to the Asset Depreciation Range (ADR) System, for assets (excluding structures) placed in service in 1971 or later, and a new Class Life (CL) System for assets placed in service before 1971 (for taxable years ending after December 1970). The CL System specifically eliminates the reserve ratio test for pre-1971 acquisitions. The ADR provisions allowed for service lives shorter than the guideline lives proposed in 1962.

And, of course, the year 1962 witnessed the enactment of the investment tax credit. This credit was suspended in 1966, restored in 1967, suspended again in 1969, restored again in 1971, and further extended and revised after that time. Each of these developments seemed to have been motivated by "prevailing economic conditions." 11

It must be admitted that this sort of analysis of historical developments lends itself to "ex post reasoning" and unintentional selectivity. For this reason, I do not want to lean too heavily on the remarks above. But the basic point of my argument does seem justifiable. Relative to what took place in the prewar period, the postwar developments were substantially in the direction of liberalization of provisions pertaining to depreciation deductions. And these developments can account for the apparent postwar descriptive inadequacy of the tax-effects hypothesis, at least relative to its descriptive power with respect to the prewar period. Moreover, given the sorts of arguments advanced in favor of these developments, it seems plausible that they were intended to have the same effects (on, e.g., profitability and investment incentives) that formal indexation would have had.

When viewed relative to prewar developments, postwar developments regarding the use of LIFO for tax reporting seem to point in the same direction (see, e.g., Butters and Niland [1949, chap. 3] for remarks on early postwar events). The increased relative importance of tax deductible interest charges also serves to alleviate the changes in real tax burdens predicted by the tax-effects hypothesis.

\section{Relative Price Changes and Real Wealth Shifts}

The tax-effects hypothesis draws heavily on the tools of partial equilibrium analyses. Ignored by its presumptions and predictions are such things as changes in relative prices and the distribution of wealth. Once the latter sorts of things are taken into account, the predictions of the

11. It is also well to note that subsidy programs such as the investment tax credit can be substantially nonneutral. Thus, they can contribute to shifts in the distribution of real wealth, such as those considered in the next section. For analyses of this feature of the investment tax credit, see, e.g., Sunley (1973) and Bradford (1978). 
tax-effects hypothesis seem much less convincing. For example, if nonzero rates of inflation are accompanied by wealth redistributions because of the sorts of assets (nominal vs. nonmonetary) held by various types of agents, then one can expect, in general, shifts in patterns of consumption. And these shifts may be relatively advantageous to firms for which fixed capital services and inventory services are important factors of production. In short, such potential shifts in demand functions can alleviate the cost function shifts predicted by the tax-effects hypothesis (because of predicted changes in real tax burdens). And they can lead to real capital gains on current holdings of units of fixed capital and units of inventory.

The evidence presented here is not based on tests dealing specifically with this issue of demand and cost function shifts. But the empirical results on, for example, firms' capital expenditure rates and rates of growth in net capital-which reflects firms' decisions about allocating real resources-seem consistent with such favorable shifts.

Additional remarks and evidence on the importance of relative price changes and changes in the distribution of real income are provided by Minarik (1978) and Nulty (1979). Remarks on evidence dealing specifically with real wealth redistribution due to capital gains and losses (realized and unrealized) are provided by Eisner (1979).

\section{The Expenditure Side of the Government Budget}

The major predictions of the tax-effects hypothesis are based on the changes in real tax burdens implied by a nonindexed income tax system and nonzero rates of inflation. This partial equilibrium approach abstracts from the critical "other side" of the government budget, the expenditure side. If the predicted changes in resources drawn from the private sector are accompanied by changes in the pattern of real governmental expenditures, there are even stronger reasons for expecting the sorts of relative price and real wealth changes mentioned above. In technical terms, the changes on the tax side may not be "distributionally neutral,' in the sense defined by, for example, McClure and Thirsk (1975).

Such changes on the expenditure side seem particularly likely when stabilization goals are actively pursued. As indicated in the section entitled Remarks on the Descriptive Adequacy of the Tax-Effects Hypothesis, this may lead to the relationships between the components of inflation rates and, say, corporate profitability and investment incentives. But the implied relationships and their interpretations would differ from those associated with the tax-effects hypothesis. In short, expected and unanticipated rates of inflation may simply be serving as proxies for governmental actions motivated by stabilization goals. Changes on the expenditure side of the government budget may also 
result from active pursuit of income transfer goals (in this regard, see, e.g., Browning and Johnson [1979]).

\section{Summary and Implications}

The general topics of interest here are the potential substantive economic effects of accounting techniques, conditional on the prevailing economic conditions and institutional structure. The joint effects of historical cost accounting methods and price-level changes were the specific objects of analysis in this paper.

It is usually argued that the failure to use indexation (i.e., the use of historical cost accounting techniques) necessarily implies that real rates of income tax will vary directly with rates of inflation. This substantive effect of mere bookkeeping methods is often predicted even though the predicted effect is recognized to have adverse implications. This is the so-called tax-effects hypothesis whose descriptive adequacy was investigated in this paper.

I inferred that the empirical results presented here are not consistent with the tax-effects hypothesis. The results are consistent with the joint hypothesis that (1) the effects of indexing the tax system were attained via the government's providing alternative options to firms (in the form of, e.g., liberalized depreciation rules), (2) firms exploited available devices (e.g., the use of debt-induced tax shields) to alleviate the changes in real tax burdens jointly implied by price-level changes and a tax code based on historical cost accounting methods, and (3) these predicted changes in real tax burdens were alleviated by favorable demand function shifts (due, e.g., to patterns of governmental expenditures, relative price changes, etc.).

In any event, what does seem most clear is that fixating exclusively on the implications of accounting techniques - for a given institutional structure and conditional on prevailing economic conditions-may not lead to a descriptively adequate model. This seems, moreover, to be a very likely result when the decision makers whose decisions are being (implicitly) modeled are among those who can alter accounting techniques or the effects of techniques. Why, for example, would firms knowingly allow their real tax burdens to increase when they can adopt techniques (e.g., accelerated depreciation methods) that prevent or mitigate the effects of such results? Why are firms not assumed to exploit other features of the prevailing rules of taxation-such as the tax deductibility of interest charges-for the same reason? And why is the government presumed to allow such increases in real tax burdens independently of their implications for the overall level of economic activity and for the pattern of real resource allocations? A model that does not account for such potential private and public sector responses 
and that also assumes rational economic behavior seems somewhat strange. More important, it seems likely to omit variables that are important for attaining descriptive adequacy. ${ }^{12}$

\section{Appendix}

\section{Remarks on Data}

Detailed descriptions of the data series used here are given in the data sources identified in the text; repeating those details here seems pointless, and I make no attempt to do this. Instead, I briefly describe the BEA capital stock data, some of the NIPA series, and the expected rates of inflation.

\section{BEA Capital Stock Data}

The BEA capital stock data pertain to fixed nonresidential business and residential capital in the United States. Detailed tabulations based on historical costs, current costs, and constant-dollar costs are presented for stocks of durable equipment and nonresidential structures owned or operated by private business and for residential capital located in the United States. These capital stock data are consistent with the data prepared by BEA for its NIPA. In addition, the data are presented under various service-life assumptions and under various depreciation methods. These data result from a larger project which also deals with stocks of business inventories.

BEA's capital stock data were obtained by applying the "perpetual inventory method" to data on investment flows. That is, data on stocks are obtained by cumulating investment flows, adjusting for withdrawals, and, for net capital stocks, adjusting for depreciation.

The data on investment flows used by BEA are those that enter the estimates of Gross National Product (GNP). Specifically, these flows consist of (1) the nonresidential and residential fixed investments that are included in the "gross private domestic investment" component of GNP and (2) the government purchases of residential capital that are included in the "government purchases of goods and services" component of GNP.

The BEA capital stock data pertain to newly produced assets and to stocks stemming from (net) acquisitions by business of secondhand items from other

12. I suspect that the same sorts of issues are relevant to areas other than the tax effects of inflation and historical cost accounting techniques. It is claimed, for example, that the FASB's recently adopted "expensing" rules for R \& D expenditures will have adverse implications for investments in $\mathrm{R} \& \mathrm{D}$ and innovative behavior (see e.g., Horwitz and Kolodny [1979]). But why would rational economic agents allow this to occur solely because of bookkeeping mechanics? Perhaps if it does occur, its occurrence is really independent of these mechanics. But those whose "oxen are gored" by its occurrence may find these mechanics and the FASB to be handy scapegoats. Or perhaps the effects of the techniques are consistent with the objectives of the "powers that be," and, as a result, these effects would have been induced via alternative routes if not by the techniques. Similar issues can be raised with respect to recent debates over oil and gas accounting and accounting for foreign currency translations (see, e.g., Collins, Dent, and O'Conner [1978]; Collins and Dent [in press]; and Dyckman and Smith [1979], with respect to oil and gas accounting; and Burns [1976] and Dukes [1978], with respect to foreign currency translations). 
sectors. Such acquisitions were, according to BEA, quite large after World War II, when private businesses acquired equipment and structures that were owned by the government during this war.

BEA used original acquisition prices to value intersector transfers of used assets other than government surplus assets. Some of these government surplus assets are also valued at their original acquisition prices. But those that were "less suited to postwar than war use" were valued at (what are claimed to be) the prices that business would have been willing to pay for new assets of equal productivity designed specifically for the civilian uses to which these government surplus assets were put. "Government-owned, privately-operated"' (GOPO) assets are excluded. (Remarks on the importance of these assets are given in Gordon [1969].)

For nonresidential fixed capital, BEA provides net capital stock data under alternative assumptions about service lives and depreciation methods (namely, SL and DDB). The results presented in the text are based on the data for service lives equal to $85 \%$ of those specified in the 1942 edition of the Internal Revenue Service's Bulletin $F$ (U.S. Department of the Treasury, Internal Revenue Service 1942). Table A1 gives the $.85 \mathrm{~F}$ lives used by BEA, and it indicates the types of assets included in BEA's categories of assets.

Various price indices were used by BEA in order to obtain its current-dollar, and the related constant-dollar, data. BEA attempts to adjust for quality changes to the extent that such changes are reflected in the contemporaneous relative prices of new and old capital goods. In general, one unit of a new item is considered to be equivalent to one unit of the old item multiplied by the ratio of the acquisition cost of the new item to the contemporaneous acquisition cost of the old item for an "overlap" time period. If there is no overlap period, BEA effects a hypothetical comparison by estimating what it would have cost to produce the new item in a period in which the old item was available.

\section{NIPA Data}

The NIPA data (as revised in 1977 and 1978) resulted from a comprehensive benchmark revision of the NIPAs of the United States completed in 1976. Definitions of some of the series used in this paper are given below.

Corporate profits before tax is the income of corporations organized for profit and mutual financial institutions that accrues to U.S. residents, measured before profits taxes, before deduction of depletion charges, after exclusion of capital gains and losses, and net of dividends received from domestic corporations. In addition to profits earned from domestic operations, this number includes net receipts of dividends and branch profits from abroad. In other important respects, this profits number is defined in accordance with U.S. federal income tax regulations.

Profits tax liability consists of federal, state, and local taxes on corporate income.

Net interest consists of interest paid by domestic business less interest received by it, plus net interest received from abroad. In addition to monetary interest flows, net interest includes interest in kind (i.e., "imputed interest"), as described in the text.

Capital consumption allowance consists of depreciation charges and accidental damages to fixed business capital. For nonfarm business, these amounts 
TABLE A1 BEA Service-Life Assumptions by Type of Asset

\begin{tabular}{lr}
\hline & \multicolumn{1}{c}{ Life } \\
Type of Asset & (Years) \\
\hline Equipment: & \\
Furniture and fixtures & 15 \\
Fabricated metal products & 18 \\
Engines and turbines & 21 \\
Tractors & 8 \\
Agricultural machinery (except tractors) & 17 \\
Construction machinery (except tractors) & 9 \\
Mining and oilfield machinery & 10 \\
Metalworking machinery & 16 \\
Special industry machinery, nec* & 16 \\
General industrial, including materials handling, equipment & 14 \\
Office, computing, and accounting machinery & 8 \\
Service industry machines & 10 \\
Electrical machinery & 14 \\
Trucks, buses, and truck trailers & 9 \\
Autos & 10 \\
Aircraft & 9 \\
Ships and boats & 22 \\
Railroad equipment & 25 \\
Instruments & 11 \\
Other equipment & 11
\end{tabular}

Nonresidential structures:
Industrial buildings

Commercial buildings $\quad 36$

$\begin{array}{ll}\text { Religious buildings } & 48\end{array}$

$\begin{array}{ll}\text { Educational buildings } & 48\end{array}$

$\begin{array}{ll}\text { Hospital and institutional buildings } & 48\end{array}$

Other nonfarm nonresidential buildings $\quad 31$

Railroad structures $\quad 51$

$\begin{array}{ll}\text { Telephone and telegraph structures } & 27\end{array}$

Electric light and power structures $\quad 30$

$\begin{array}{ll}\text { Gas structures } & 30\end{array}$

Other public utility structures $\quad 26$

Farm nonresidential buildings $\quad 38$

Petroleum, gas, and other mineral drilling and exploration 16

All other private nonresidential structures $\quad 31$

Residential capital:

1-4-unit structures:

New

Additions and alterations $\quad 40$

5 or more unit structures:

Additions and alterations $\quad 32$

Mobile homes $\quad 16$

Nonhousekeeping $\quad 40$

$\begin{array}{ll}\text { Equipment } & 11\end{array}$

Government-owned, privately operated:

Atomic Energy Commission:

Equipment

$\begin{array}{ll}\text { Structures } & 32\end{array}$ 
TABLE A1 (Continued)

\begin{tabular}{lc}
\hline & $\begin{array}{c}.85 \mathrm{~F} \\
\text { Life } \\
\text { Type of Asset }\end{array}$ \\
\hline National Aeronautics and Space Administration: \\
$\quad$ Equipment & 15 \\
Structures: Manufacturing & 32 \\
Structures: Nonmanufacturing & 37 \\
Department of Defense: & 19 \\
Equipment & 32 \\
Structures & 22 \\
Maritime Administration & \\
\hline
\end{tabular}

SourCE.-U.S. Department of Commerce, Bureau of Economic Analysis (1976), pp. T-6-T-7, table B.

${ }^{*}$ nec $=$ not elsewhere clarified.

are as reported on federal income tax returns. For farms, they are based on NIPA calculations.

Capital consumption adjustment equals the tax-return-based capital consumption allowance less a capital consumption allowance based on estimates of economic service lives, SL depreciation, and replacement cost.

Gross domestic product is a measure of production that excludes the NIPA "rest-of-the-world" production. Specifically, it is the market value of goods and services produced by labor and property located in the United States.

\section{Expected Rates of Inflation}

The expected annual rates of inflation used here were kindly supplied by G. William Schwert (University of Rochester). His estimates resulted from timeseries analyses of monthly and annual percentage changes in the Consumer Price Index. The specific results used here are those associated with what appeared to be the most adequate time-series model, relative to those considered by Schwert and to the strict martingale model.

Schwert's analyses encompassed four different methods of forecasting annual rates of inflation. Two methods involved computing forecasts of annual rates from forecasted monthly rates, for the months within each calendar year for which a forecast was desired. The other two methods involved forecasting annual rates of inflation with models applied directly to annual data. Some details on the four methods are given below.

Forecast method no. 1: Annual forecasts based on one-step-ahead predictions of monthly rates of inflation. Model applied to monthly data is first-order moving average model for first differences (i.e., the so-called IMA(1,1)). Consecutive one-step-ahead forecasts for the months of a given year are summed to get the implied forecast for the entire year, for the years 1913-75. The model for monthly rates was separately estimated for subperiods ranging in length from 6 to 12 years (i.e., 72-144 months). Thus, the monthly forecast errors are actually residuals. This is, in general, not the case for the corresponding annual forecast errors.

Forecast method no. 2: Forecasts of annual rates of inflation are based on 
consecutive $K$-step-ahead forecasts of monthly rates for the months within a year of interest, for $K=1,2, \ldots, 12$. The model used for a given year's monthly forecasts is estimated using monthly data from January 1913 to December of the preceding year. (Thus, the one-step-ahead forecast from the model estimated using data up to December of a given year is always for January of the next year, the two-step-ahead forecast is for February of the next year, etc.) The monthly forecasts for a given year were summed to get the implied annual forecast for that year, for each of the years 1916-75. (Data from 1913 to 1915 provided "start up" data.)

Forecast method no. 3: Forecasts of annual rates are based on the secondorder autoregressive model applied directly to annual data for the years 1912-76. The first forecast is for 1914. Forecast errors are, therefore, residuals from the estimated model.

Forecast method no. 4: Forecasts of annual rates are based on the thirdorder moving average model applied to first differences of annual data from the period 1912-76. The first forecast is for 1914. ("Back forecasting" was used here.)

Various properties of the annual forecast errors induced by these four methods and the strict martingale model (applied to annual data) were examined. Bias, serial correlation, standard deviations, and mean-squared errors were among the properties examined, for the overall period 1916-75 and for the two subperiods 1916-46 and 1947-75. On the basis of these results, I inferred that forecast method no. 1 is the more adequate model.

At first glance, it might seem inappropriate to use this model, which is based on monthly data, in conjunction with our annual data (i.e., the BEA, NIPA, and IRS data). But these other data presumably reflect the effects of decisions that were made and events that occurred throughout each year, rather than at, say, the beginning of each year. Changes in expected rates of inflation are among the potential intrayear influences on these decisions and events. The expected annual rates derived from our expected monthly rates can be viewed as summarizing the inflation expectations corresponding to the annual observations on our other variables of interest. As with other sorts of aggregation, this type of summarization may involve a "loss of information" (on, e.g., the timing of intrayear changes in inflation expectations and the timing of changes in investment plans). I do not believe, however, that it involves any internal theoretical inconsistency.

\section{References}

Aaron, Henry J., ed. 1976. Inflation and the Income Tax. Washington, D.C.: Brookings.

Bradford, David F. 1978. Tax neutrality and the investment tax credit. Working Paper no. 269, National Bureau of Economic Research, Cambridge, Mass., August.

Browning, E. K., and Johnson, W. R. 1979. The Distribution of the Tax Burden. Washington, D.C.: American Enterprise Institute.

Burns, J. M. 1976. Accounting Standards and International Finance. Washington, D.C.: American Enterprise Institute.

Butters, J. Keith, and Niland, P. 1949. Inventory Accounting and Policies. Cambridge, Mass.: Harvard University Press.

Cagan, Phillip, and Lipsey, Robert E. 1978. The Financial Effects of Inflation. Cambridge, Mass.: National Bureau of Economic Research. 
Cohen, R. M. 1975. Investment behavior, the measurement of depreciation, and tax policy. American Economic Review (March), pp. 59-74.

Collins, Daniel, and Dent, W. In press. The proposed elimination of full cost accounting in the extractive petroleum industry: an empirical assessment of the market consequences. Journal of Accounting and Economics (Spring).

Collins, Daniel; Dent, W.; and O'Conner, M. 1978. Market effects of the elimination of full cost accounting in the oil and gas industry. Financial Analysts Journal (November/December), pp. 48-57.

Commerce Clearing House. 1978. 1978 Depreciation Guide. Commerce Clearing House, July.

Coughlan J. D., and Strand, W. K. 1969. Depreciation: Accounting, Taxes and Business Decisions. New York: Ronald.

Cramer, H. 1946. Mathematical Methods of Statistics. Princeton, N.J.: Princeton University Press.

Davidson, Sidney, and Weil, Roman L. 1976. Inflation accounting: implications of the FASB proposal. In Aaron, ed., 1976.

Dukes, R. E. 1978. An Empirical Investigation of the Effects of Statement of Financial Accounting Standards No. 8 On Security Return Behavior. Stamford, Conn.: Financial Accounting Standards Board, December.

Dyckman, Thomas, and Smith, Abbie. 1979. A Study of the Effect of the Issuance of the Exposure Draft and FASB Statement 19 on the Returns of Oil and Gas Company Securities. Stamford, Conn.: Financial Accounting Standards Board, January.

Eisner, Robert. 1979. No tax relief on capital gains. Challenge (January/February).

Fama, E. F. 1979. Stock returns, real activity, inflation and money. Unpublished manuscript, University of Chicago, March.

Federal Reserve System, Board of Governors. 1977. Industrial Production: 1976 Edition. Washington, D.C.: Government Printing Office, December.

Feldstein, Martin. 1979a. Adjusting depreciation in an inflationary economy: indexing versus acceleration. Working Paper no. 395, National Bureau of Economic Research, Cambridge, Mass., September.

Feldstein, Martin. 1979b. Adjusting tax rules for inflation-capital gains and capital income. Tax Review' (January).

Gordon, R. J. 1969. $\$ 45$ billion of U.S. private investment has been mislaid. American Economic Review (June), pp. 221-38.

Granger, C. W. J., and Newbold, P. 1974. Spurious regressions in econometrics. Journal of Econometrics (July), pp. 111-20.

Grant, E. L., and Norton, P. T. 1955. Depreciation. New York: Ronald.

Griliches, Zvi, ed. 1971. Price Indexes and Quality Change. Cambridge, Mass.: Harvard University Press.

Hall, Robert E., and Jorgenson, Dale W. 1967. Tax policy and investment behavior. American Economic Review (June), pp. 391-414.

Hall, Robert E., and Jorgenson, Dale W. 1971. Application of the theory of optimum capital accumulation. In Gary Fromm (ed.), Tax Incentives and Capital Spending. Washington, D.C.: Brookings.

Holland, D. M., and Meyers, S. C. 1977. Trends in corporate profitability and capital costs. Working Paper 937-77, Massachusetts Institute of Technology, Sloan School of Management, May.

Hong, Hai. 1977. Inflation and the market value of the firm: theory and tests. Journal of Finance (September), pp. 1031-48.

Horwitz, B., and Kolodny, B. 1979. Mandated formatting of external reports: an analysis of the financial reporting of research and development outlays. Unpublished manuscript, May.

Kim, Moon K. 1979. Inflationary effects in the capital investment process: an empirical examination. Journal of Finance (September), pp. 941-50.

Kurz, Mordecai. 1979. A strategic theory of inflation. Technical Report no. 283, Stanford University, IMSSS, April.

McCarthy, C. F. 1968. The Federal Income Tax: Its Sources and Applications. Englewood Cliffs, N.J.: Prentice-Hall. 
McCarthy, C. F. 1974. The Federal Income Tax: Its Sources and Applications. 3d ed. Englewood Cliffs, N.J.: Prentice-Hall.

McClure, C. E., and Thirsk, W. R. 1975. Simplified exposition of the Harberger model I: tax incidence. National Tax Journal (March), pp. 1-27.

Meadoes, Edward. 1979. How Congress ought to cut taxes. Fortune (December 31), pp. 36-39.

Mertens, Jacob, Jr. 1973. The Law of Federal Income Taxation. Vol. 4. Chicago: Callaghan \& Co.

Miller, Merton. 1977. Debt and taxes. Journal of Finance (May), pp. 261-75.

Minarik, Joseph J. 1978. Who wins, who loses from inflation? Brookings Bulletin (Summer).

Montgomery, Robert H. 1917. Income Tax Procedure, 1917. New York: Ronald.

Montgomery, Robert H. 1936. Federal Income Tax Handbook, 1936-1937. New York: Ronald.

Montgomery, Robert H.; Taylor, C. B.; and Richardson, M. E. 1946. Federal Taxes on Corporations, 1945-1946. Vol. 1, Gross Income and Deductions. New York: Ronald.

Montgomery, Robert H.; Taylor, C. B.; and Richardson, M. E. 1947. Federal TaxesCorporations and Partnerships, 1946-1947. Vol. 1, Gross Income and Deductions. New York: Ronald.

Nelson, C. R. 1976. Inflation and capital budgeting. Journal of Finance (June), pp. 923-32.

Nulty, L. E. 1979. How inflation hits the majority. Challenge (January/February), pp. 32-38.

Shoven, J. B., and Bulow, J. I. 1975. Inflation accounting and non-financial corporate profits: physical assets. Brookings Papers on Economic Activity 3:557-98.

Shoven, J. B., and Bulow, J. I. 1976. Inflation accounting and non-financial corporate profits: financial assets and liabilities. Brookings Papers on Economic Activity $1: 15-57$.

Sunley, Emil M., Jr. 1973. Towards a more neutral investment tax credit. National Tax Journal (June), pp. 209-20.

Tideman, T. N., and Tucker, D. P. 1976. The tax treatment of business profits under inflationary conditions. In Aaron, ed., 1976.

Von Fustenberg, G. M. 1977. Corporate investment: does market valuation matter in the aggregate? Brookings Papers on Economic Activity 2:347-408.

U.S. Department of Commerce. 1977-78. Survey of Current Business.

U.S. Department of Commerce, Bureau of Economic Analysis. 1976. Fixed Nonresidential Business and Residential Capital in the United States, 1925-1975. Washington, D.C.: Government Printing Office.

U.S. Department of Commerce, Bureau of Economic Analysis. 1977. The National Income and Product Accounts of the United States, 1929-1974: Statistical Tables. Washington, D.C.: Government Printing Office.

U.S. Department of the Treasury, Internal Revenue Service. 1942. Bulletin F: Income Tax, Depreciation and Obsolescence, Estimated Useful Lives and Depreciation Rates. 3d ed. Washington, D.C.: Government Printing Office, January.

U.S. Department of the Treasury, Internal Revenue Service. 1946-52. Internal Revenue Bulletin, Cumulative Bulletin, I.T. 3818. Washington, D.C.; Government Printing Office. 